\title{
ARCHITEKTURA HORNICKÝCH SÍDLIŠŤ NA SKLONKU PŘEMYSLOVSKÉ DOBY
}

\author{
JIŘÍ CRKAL - KRYŠTOF DERNER - PETR HRUBÝ - PETER MILO
}

\begin{abstract}
Abstrakt: Hlavni řě̌enou otázkou předloženého př́spěvku je, zda vỉbec existovala specifická hornická stavební kultura. Na úrovni urbanismu jsou odlišnosti od mést i vesnic evidentní. V poznání jeho formy pomáhá výrazně geofyzikální výzkum. Oproti tomu rozšiřený předpoklad, že pro hornická sídliště jsou typické obytné zemnice, nemá oporu ve hmotných pramenech. Nejnovějši výzkumy na jihlavských Starých Horách přinášeji hlavně znalost detailů konstrukce zahloubených staveb. Vobecné rovině nelze za hlavni dưvody odlišnosti stavebnictví v hornickém prostředi považovat jejich provizorní charakter, naopak souhlasime s malou potřebou individuálních chladných skladovacích prostor. Jak ukazuje obdobná situace na vesnicích, je možné, že podsklepení bylo přesto přejato ze soudobých měst bez ohledu na jeho nezbytnost, jako součást kolonizačního typu domu. Vedle nich existovaly $i$ větši sklepy komunitního významu, jak dokazuje př́klad z Kremsigeru v Krušných horách.
\end{abstract}

Klíčová slova: hornická sídliště - zemnice - sklepy - vrcholný středověk-montánní archeologie.

\section{Architecture of mining settlements in the late Přemyslid era}

\begin{abstract}
The main subject of this article is whether there existed specific building culture associated with mining. At the urbanist level, differences from towns and villages are obvious. Geophysical survey plays an important part in the study of the urbanist forms of these dwellings. In contrast, the presumption that mining settlements typically consisted of residential sunken features was not confirmed by material evidence. The latest research in the Staré Hory settlement, Jihlava brought detail information about the construction of sunken features. In general terms, the main reason for the differences in buildings situated in mining environments is not their provisional character. On the other hand, the authors believe there was little need for individual cool storage spaces. As illustrated by a similar situation in villages, cellars might have been adopted from contemporary towns regardless of necessity, as part of the colonization type of house. There were also large communal cellars, as demonstrated by an example from Kremsiger in the Krušné hory mountains.
\end{abstract}

Key words: mining settlements - sunken features - cellars - high Middle Ages - mining archaeology.

\section{Úvod: Hornická sídliště jako odkladiště nepohodlných konceptů}

Pro architekturu středověkých hornických sídlišt' je charakteristické, že má jen minimální odraz v písemných pramenech a v ikonografii nezanechala stopy žádné. Její poznání je tedy možné jen prostř̌ednictvím archeologických výzkumů, a to se vší nejistotou, kterou to obnáší. Jedním z rizik je, že se hornická sídliště stanou jakousi šedou zónou, kam budou s poukazem na jejich blíže neupřesněnou specifičnost odsouvány teoretické koncepty, které jsou jinde již opouštěny. Př́íkladem toho je tuzemská diskuse o hypotetických vrcholně středověkých zemnicích, které by údajně měly být výrazněji zastoupeny pouze $\mathrm{v}$ hornickém prostředí (Vařeka 2002, 274; Holub a kol. 2003, 81; kriticky Klápště 2005, 3).

Součástí problému je i snaha vyrovnat se s otázkou častějších dokladů obytnosti staveb na lokalitě Sekanka s poukazem na její vztah k hornickému prostředí (Richter 1982, 210, obr. $149,212,213$, obr. 151). Minimálně dispozicí a spíše volnější vazbou na doly by se ovšem mezi hornickými sídlišti jednalo o unikát. Kritická a fundovaná diskuse o hospodářském podílu hornictví či o báňském charakteru Sekanky by v každém př́ípadě přesáhla rámec př́íspěvku.

$\mathrm{K}$ představě dominance zemnic na hornických sídlištích vedla $\mathrm{v}$ českém prostředí nepochybně i energická obhajoba jejich obytnosti W. Schwabenickym, autorem výzkumů na známém saském hornickém sídlišti Treppenhauer (naposledy 2009, 226-230). Ze Schwabenickyho argumentace lze vyvodit, že v pozadí jeho úvah stojí dva předpoklady o odlišných podmínkách zástavby hornických sídlišt' ve srovnání s městy: 1) Principiální provizornost osídlení u dolů 
nemotivuje ke stálejší zástavbě. 2) Horníci nepotřebují chladné skladovací prostory: zahloubené stavby jsou proto zemnicemi.

Následujících 15 let přineslo zejména v České republice nové objevy hornických sídlišt’ se zahloubenými stavbami i bez nich (obr. 1). Další výrazné rozšiřrení našich poznatků o hornické zástavbě přinášejí nové plošné geofyzikální průzkumy a letecké laserové skenování. Nezdá se však, že by tato zjištění posunula diskusi o povaze hornické zástavby někam dál. Faktem je, že např́iklad jednoznačným závěrům ve sporu „zemnice či sklepy“ se nové montánně archeologické bádání z dobrých důvodů spíše vyhýbalo. Starší i novější studie k dané problematice (Hrubý 2011; Schwabenicky 2009) byly mimo okruh montánní archeologie kriticky vyhodnoceny jen částečně. Pokusme se proto podat přehled poznatků o urbanismu a stavbách hornických sídlišt'. Zaměříme se zejména na známky obytnosti hornických ,zemnic“, v obecné rovině se budeme vyrovnávat s předpoklady odlišných podmínek vývoje staveb na hornických sídlištích. Otázkou, k níž by vše mělo směřovat, je, zda vůbec existuje něco jako svébytná hornická stavební kultura.

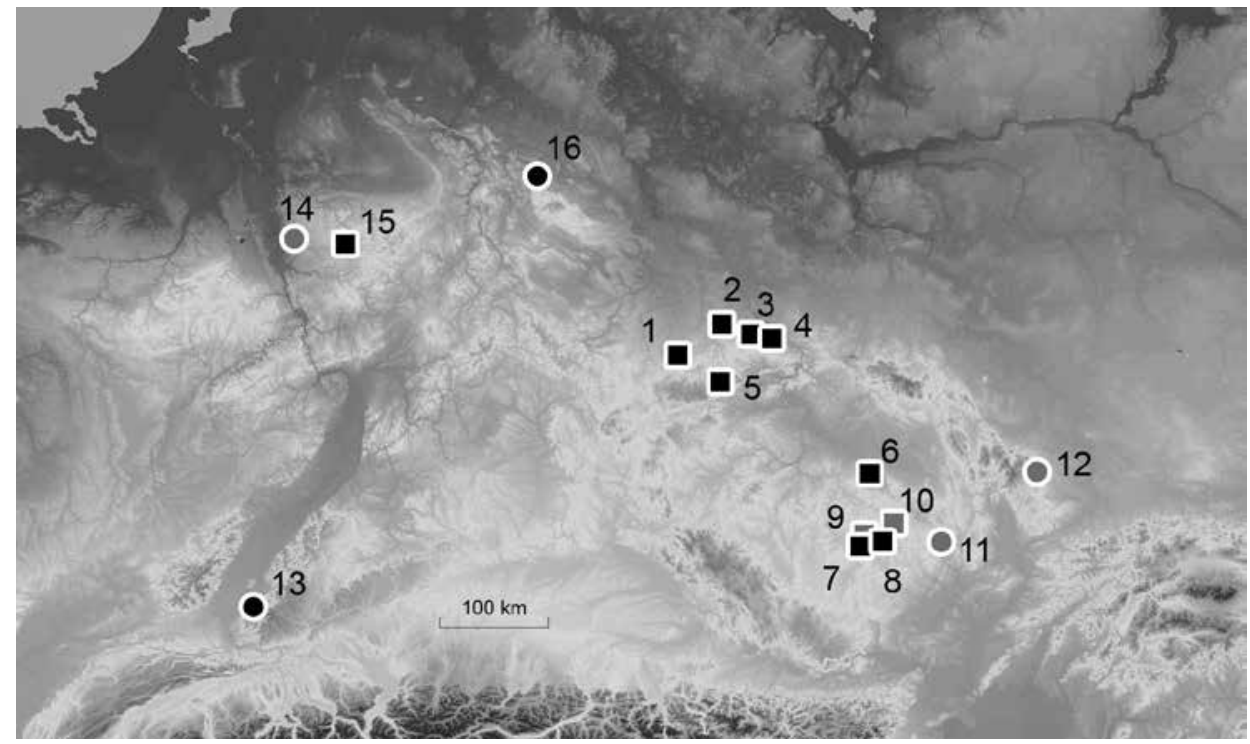

Obr. 1. V textu zmiňovaná hornická sídliště. Čtverec -s převahou staveb se zahloubenou částí; kolo - s převahou nadzemních staveb; černě - zkoumány odkryvem; šedě - zkoumány nedestruktivními metodami. 1 - Hohenforst (Kirchberg); 2 - Treppenhauer (Frankenberg) a Biege (Schönborn-Dreiwerden); 3 - Freiberg, Rammelsberg (Hilbersdorf), Hilbersdorf; 4 - Dippoldiswalde; 5 - Kremsiger (Př́́sečnice); 6 - Kutná Hora; 7 - Cvilínek (Černov); 8 - Staré hory (Jihlava); 9 - Vyskytná; 10 Buchberg (Utín); 11 - Havírna (Štěpánov nad Svratkou); 12 - Altenberg/Erlitz (Zlaté Hory); 13 - Geißmättle (Sulzburg); 14 - Silberkaule (Engelskirchen-Loope); 15 - Altenberg (Müsen); 16 - Johanneser Kurhaus (Clausthal-Zellerfeld).

Abb. 1. Im Text erwähnte Bergbausiedlungen. Quadrat - überwiegend Bauten mit eingetieftem Teil; Kreis - überwiegend oberirdische Bauten; schwarz - durch Freilegung untersucht; grau - mit zerstörungsfreien Methoden untersucht. 1 - Hohenforst (Kirchberg); 2 - Treppenhauer (Frankenberg) und Biege (Schönborn-Dreiwerden); 3 - Freiberg, Rammelsberg (Hilbersdorf), Hilbersdorf; 4 - Dippoldiswalde; 5 - Kremsiger (Přísečnice); 6 - Kutná Hora; 7 - Cvilínek (Černov); 8 - Staré hory (Jihlava); 9 - Vyskytná; 10 - Buchberg (Utín); 11 - Havírna (Štěpánov nad Svratkou); 12 - Altenberg/Erlitz (Zlaté Hory); 13 - Geißmättle (Sulzburg); 14 - Silberkaule (Engelskirchen-Loope); 15 - Altenberg (Müsen); 16 - Johanneser Kurhaus (Clausthal-Zellerfeld).

\section{Urbanismus hornických sídlišt'}

Představa o neorganizované hornické zástavbě byla archeologickými výzkumy opakovaně zpochybněna (k tomu Nováček 1994). Na druhé straně neexistují žádná typizovaná hornická sídliště. V širokém spektru uspořádání středověkých hornických sídlišt' nenalezneme jednotný vzorec: stupeň organizace a logika uspořádání domů se značně liší od jednoho ke druhému. 


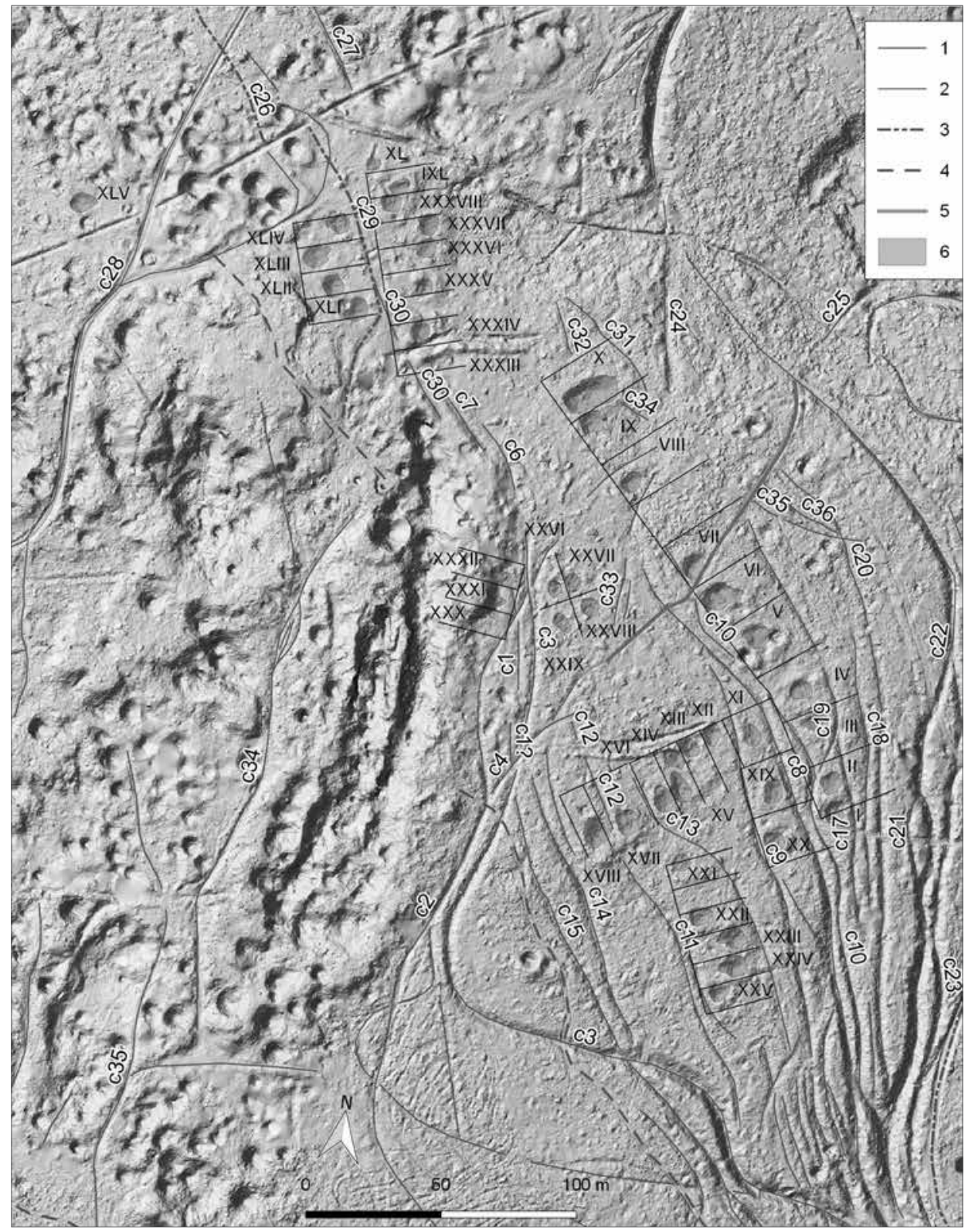

Obr. 2. Hypotetická parcelace a sít' cest na Kremsigeru. 1 - hranice parcel; 2 - úvozové cesty; 3 - cesty na otisku stabilního katastru (1843); 4 - recentní cesty; 5 - vodní kanál; 6 - domy. Podle Derner 2018.

Abb. 2. Hypothetische Parzellierung und Wegenetz auf dem Kremsiger. 1 - Parzellengrenze; 2 - Hohlwege; 3 - Wege auf einem Abdruck des Stabilen Katasters (1843); 4 - rezente Wege; 5 - Wasserkanal; 6 - Häuser. Nach Derner 2018.

Z nověji zkoumaných českých lokalit patří $\mathrm{k}$ nejpromyšleněji organizovaným sídliště Kremsiger v Krušných horách, kde pozorujeme dokonce náznak ortogonálního uspořádání s pravidelnými rozestupy domů stojících na parcelách o šířkách 19 či 9,5 m (obr. 2). Do nejrozšířenější skupiny osad - s liniovým uspořádáním staveb rovnoběžně s důlními díly - řadíme 
na Českomoravské vrchovině hornické sídliště u Vyskytné a část historického důlního centra Buchberg u Utína, v jejichž poznání hrála hlavní roli magnetometrie. Na Vyskytné je většina půdorysů staveb uspořádána $v$ liniích zhruba rovnoběžných s hlavním jámovým tahem (obr. 3). Takových linií je v areálu umístěno hned několik, přičemž nejběžnější vzdálenost mezi sousedícími podpovrchovými strukturami, považovanými za relikty staveb, je v rozpětí $4-10 \mathrm{~m}$. V patnácti př́ípadech je vzájemná vzdálenost do $1 \mathrm{~m}$, u čehož lze hypoteticky uvažovat bud' o nesoučasné existenci dvou stavebních struktur, nebo o zdvojené stavbě. V historickém důlním středisku Buchberg vykazují anomálie, které jsou situovány nejblíže k dochovaným reliktům důlních pracovišt' (vzdálenost 20 až $40 \mathrm{~m}$ ), liniové uspořádání souběžně s důlním tahem. V ostatních částech geomagneticky zkoumané plochy sídliště se anomálie považované za relikty staveb objevují spíše v neuspořádaných shlucích. Vzájemné vzdálenosti predikovaných staveb jsou v souvislých liniích velmi malé a nezř́ídka činí 1 až 2 , nejvýše $3 \mathrm{~m}$. Pravidelněji je u shlukových částí tohoto extenzivně rozvinutého sídliště dodržována vzájemná vzdálenost mezi 6 a $16 \mathrm{~m}$ (Derner-Hrubý 2018, obr. 8 na s. 215). Po obou stranách obvalového tahu se nacházejí domy také na lokalitě Altenberg/Erlitz ve Zlatých Horách (Večeřa-Večeřová 2008).

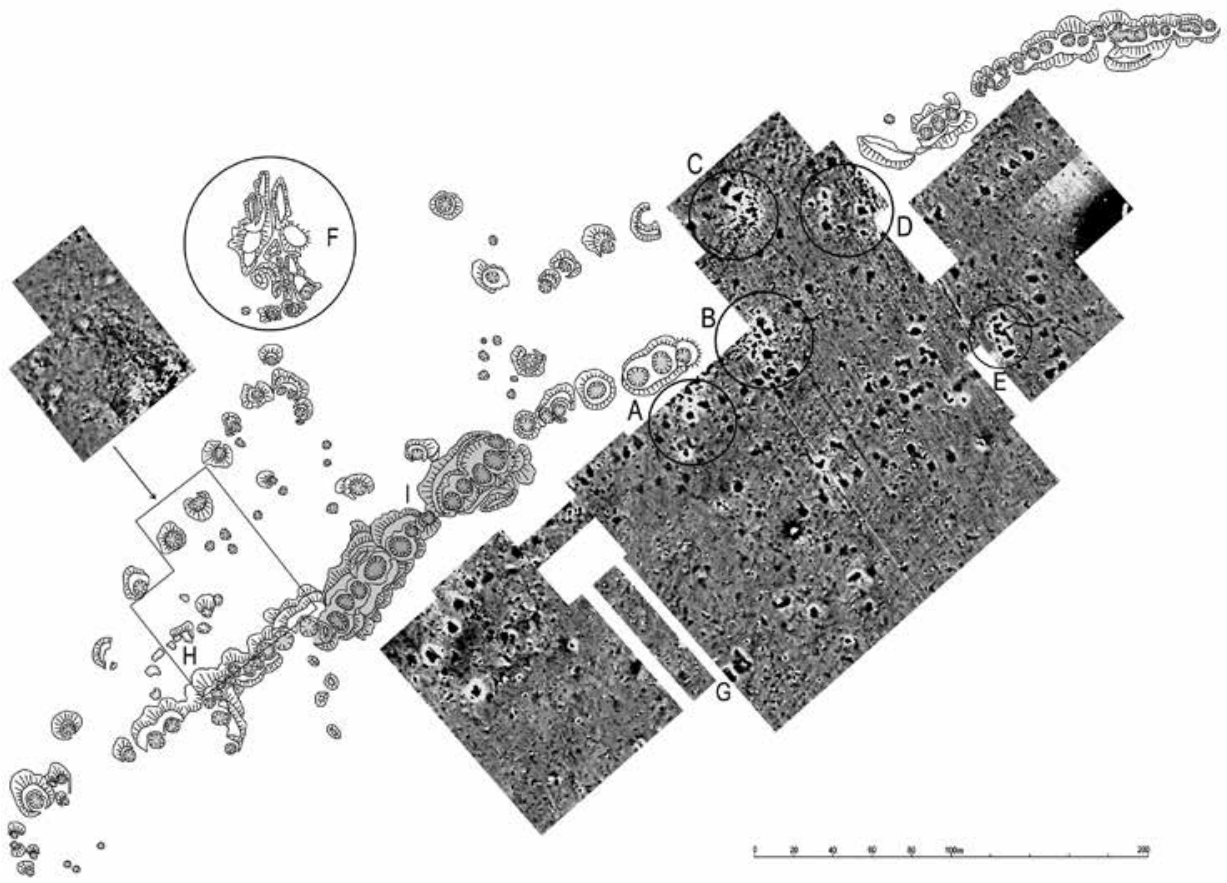

Obr. 3. Zaniklé stř̌edověké důlní stř̌edisko jižně od Vyskytné. Geomagneticky zjištěné podpovrchové anomálie interpretované jako sídlištní a další archeologické struktury. A, C-D - magnetické anomálie považované za indikátory kovářských pracovišt'; B - geomagnetická anomálie se struskami po hutnictví polymetalických rud; E - geomagnetická anomálie indikující podpovrchové struktury složitější dispozice; $\mathbf{F}$ - konvexní reliéfní tvary související možná s primární úpravou rud; G - geomagnetická anomálie indikující dispozičně složitější podpovrchové stavební struktury; H-geomagneticky proměřená plocha s výskytem olověných slitků a úkapků a s konkávními terénními tvary, které lze považovat za tzv. zemnice; I - souvislé dolové pole odpovídající stř̌edověké důlní míře. Geomagnetické měření ÚAM FF MU.

Abb. 3. Wüstung eines mittelalterlichen Grubenzentrums südlich von Vyskytná. Als Siedlungsstruktur und weitere archäologische Strukturen geomagnetisch festgestellte Oberflächenanomalien. A, C-D - magnetische Anomalien, die als Indikatoren für Schmiedearbeitsstätten angesehen werden; B - geomagnetische Anomalie mit Hüttenschlacken polymetallischer Erze; E - Oberflächenstrukturen mit eine kompliziertere Disposition indizierende geomagnetische Anomalie; F - möglicherweise mit primärer Erzverarbeitung zusammenhängende konvexe Reliefformen; G - von der Anlage her kompliziertere Oberflächenbaustrukturen indizierende geomagnetische Anomalie; $\mathbf{H}$ - geomagnetisch vermessene Fläche mit Ofensauund Gusstropfenvorkommen und konkaven Geländeformen, die als sog. Grubenhäuser angesehen werden können; I - dem mittelalterlichen Grubenmaß entsprechende zusammenhängende Grubenfelder. Geomagnetische Vermessung Institut für Archäologie und Museologie der Phil. Fak. Der Masaryk-Universität. 
Problematické asi bylo zřízení obydlí na lokalitě Havírna v oblasti svratecké klenby (Doležel-Sadílek 2004). I zde pozorujeme snahu o umístění staveb podél důlních pracovišt', avšak prríkrý svah nutil stavitele k improvizaci, takže stavby stojí na umělých plošinách, vzniklých navršením hlušiny i zářezem.

Na lokalitě Cvilinek bylo uskupení hornických obydlí několik a podobně jako u jihlavských Starých Hor, Vyskytné či důlního centra Buchberg nebylo zdejší sídliště soustředěno na jediné místo. Nově byly v jihozápadní (archeologicky nekopané) části areálu zjištěny geomagnetické anomálie, které naznačují existenci sídliště podél předpokládaných důlních pracovišt'. Osa takto uvažované zástavby odpovídá směru blízké rudní struktury (obr. 4). Tato část sídliště má překvapivě podobu ulicovky.

Na konci spektra se nachází areály, kde jsou stavby a obydlí neuspořádané a shlukové. Tomuto půdorysnému obrazu se ze sídlišt' Českomoravské vrchoviny blíží nejvíce jihlavské Staré Hory. Obdobný prrípad sousedství staveb a šachet na středisku Altenberg v Siegerlandu vedl $\mathrm{k}$ úvaze o souvislosti s formou držby dolů, v tomto př́ípadě lénhavířskou, kdy provozovatelé dolů pracovali nájemně na dolech prvotních držitelů propůjček (Lobbedey 1998, 38, Abb. 5; srov. Nováček 1994, 167).

Vnitřní členění areálů na parcely a jejich zástavba nám většinou unikají. Výjimkou je náznak rozměření parcel na lokalitě Kremsiger (viz výše) nebo situace na sídlišti Silberkaule v Severním Porýní-Vestfálsku, kde byly shluky terénních zářezů různé velikosti interpretovány jako stanoviště hlavních a vedlejších budov hornických usedlostí (Gechter 2003, 158-160, Abb. 2). Jako o usedlostech bychom mohli uvažovat o třech shlucích budov, které se rýsují na magnetogramu Vyskytné. Do určité míry je zde naznačeno dvorcové ortogonální uspořádání o výměře $16 \times 12 \mathrm{~m}$ (obr. 3:G). Podobně lze hodnotit soustavu anomálií ve východní části proměřené plochy (obr. 3:E).

Komplex budov se sklepem, resp. podsklepeným domem a nadzemním jednoprostorovým domkem se podařilo odkrýt na sídlišti na lokalitě Geißmättle u Sulzburgu (Spiong 1999, 79). Stavby lehčí konstrukce se mohou projevit koncentrací hřebíků při detektorovém průzkumu (Derner 2018, 240, obr. 143 na s. 241).

$\mathrm{V}$ areálech hornických sídlišt' téměř nenalézáme přesvědčivé doklady sanitární a komunitní infrastruktury. Výjimkou je jen odpadní jáma a studna na lokalitě Treppenhauer (Schwabenicky 2009, 243). Nově byl na sídlišti Kremsiger objeven vodní kanál směřující od zdroje vody do středu komunitní plochy sídliště, i když jeho středověké stáří ani sanitární funkce nejsou nezpochybnitelné (Derner 2018, 257). Unikátním volně stojícím zařízením komunitního významu je velká podkovovitá pec na lokalitě Altenberg v Siegerlandu, nově interpretovaná jako chlebová (Dahm-Lobbedey 1998, 121; Zeiler-Garner-Golze 2016, 197).

\section{Typ a konstrukce staveb}

Spektrum staveb je menší než ve městech. Doloženy byly jen domy, kovárny a sauny, resp. lázně. $Z$ hlediska konstrukce lze říci, že hornické stavby přebírají zvyklosti dané oblasti. Na území Svaté říše římské jsou to dřevohliněné stavby se zahloubenými prostorami i bez nich (obr. 1).

\section{Nadzemní stavby}

Pro čistě nadzemní domy v této oblasti je charakteristické velmi prosté řešení s jedinou místností vytápěnou pecí, méně často ohništěm. Konstrukce je doložena sloupková s vyplétanými stěnami na lokalitě Johanneser Kurhaus v Harzu u domu o rozměrech $4 \times 6 \mathrm{~m}$ z fáze $3 \mathrm{~A}$ (Alper-Römer-Streh1 2003, 104-106). Domy se základovými trámy spočívajícími ve žlábcích, či na podložních kamenech měly (soudě dle stavební tradice v místech výskytu) stěny štenýřové, či hrázděné konstrukce. Kovárna této konstrukce o rozměrech $3,15 \times 3,3$ m byla odkryta ve fázi $3 \mathrm{~B}$ na lokalitě Johanneser Kurhaus (Alper-Römer-Strehl 2003, 121-122), na lokalitě Altenberg jedna stavba této konstrukce. Na lokalitě Treppenhauer bylo dokumentováno 15 nadzemních domů 
o obytné ploše $12-20 \mathrm{~m}^{2} \mathrm{~s}$ pecí. V případě velkého domu $8 \mathrm{~F} / \mathrm{O} 1$ o $41 \mathrm{~m}^{2}$ se jednalo o konstrukci se svislými sloupy vetknutými do na sucho kladené podezdívky, což se dá považovat za přechod od konstrukce sloupové ke štenýřové. Fragmentární půdorysy tří hypotetických nadzemních domů na jihlavských Starých Horách svědčí o sloupové konstrukci. Roubená stavba malých rozměrů s velkou pecí na sídlišti Altenberg byla nejspíš lázní, a nikoliv obydlím. Velmi subtilní podezdívky, nebo jen otisky dřevěných trámů, nemluvě už o možnosti výskytu sloupových staveb či staveb s vyplétanými stěnami, se v terénu nemusí nijak projevovat, což by nás mělo vést k opatrnosti při interpretaci nevýrazného terénního reliéfu mezi zahloubenými stavbami jako „prázdného“.

\section{Zahloubené stavby}

Ve středoevropském prostoru od Krušných hor po Českomoravskou vrchovinu převládají na hornických sídlištích zahloubené dřevohliněné stavby. Mimo tuto oblast jsou známy ve zděné podobě na důlních střediscích Altenberg v Siegerlandu nebo Geißmättle u Sulzburgu v jižním Schwarzwaldu. Problematická je rekonstrukce jejich nadzemních částí a s tím související nedořešená otázka, zda se jedná o obytné zemnice, či suterény nadzemních domů.

Prvním zkoumaným hornickým sídlištěm se zahloubenými stavbami byl Altenberg v hornatině Siegerland, jehož existence pokrývá celé 13. století (Lobbedey 1998). Těchto staveb zde bylo odkryto šestnáct, s jedinou výjimkou tvořily jejich stěny jílem pojené zídky o síle kolem $50 \mathrm{~cm}$. Výměra zahloubených prostor je na sídlišti velmi kolísavá a zahrnuje i hodnoty zřetelně „neobytné“ (obr. 5). Absence otopných zařízení, a naopak stopy nadzemních pater a jejich vybavení v zásypu (malta, kachle) vedla autory k jejich interpretaci jako sklepů. I u vyhořelých sklepů ale síla požárových vrstev dosahuje maximálně $20 \mathrm{~cm}$ a s jedinou výjimkou se nachází až výše v zásypu. Zajímavým detailem jsou charakteristická sklepní okénka se strmě stoupajícím parapetem u dvou stratigraficky mladších sklepů. Patrně vzhledem k tomu, že se v terénu nerýsují rozsáhlejší plošiny a nebyly doloženy navazující vnější konstrukce, předpokládají autoři nastavění nadzemních pater přímo na koruny zdí sklepů. Stavbu dřevohliněné konstrukce se slabším zahloubením jen $0,6 \mathrm{~m}$ (na nalezišti 4) označují autoři za zemnici, její rozměry $2,5 \times 2,5 \mathrm{~m}$ však podle nás obytnou funkci vylučují.

Sídliště na lokalitě Treppenhauer vzniklo nejdříve ve druhé třetině 13. století a dožilo se první poloviny 14. století. Zkoumáno bylo devět zahloubených dřevohlinitých staveb, hlubokých v průměru $2 \mathrm{~m}$ (obr. 6). Pece jsou doloženy jen u dvou nápadně malých, z nichž u objektu 6F/O9 byly nalezeny zároveň sloupové jamky vnější konstrukce. W. Schwabenicky je oprávněně považuje za podzemní prostory lázní (2009, 72-77). Domnělá ohniště v úrovni podlahy u ostatních zemnic jsou dokládána pouze kumulací uhlíků u stavby 6F/O8 (Schwabenicky 2009, 44) a propálenou plochou na podlaze stavby 5G/O1, které však mohou být stopou požáru (kriticky Kenzler 2008, 291; Stephan 2009/2010, 496). Vnější konstrukce je doložena u velké „dvojité“ zemnice 6F/O8, kde podél delších stěn probíhal pruh zetlelého dřeva, resp. kamenná podezdívka. Schwabenicky považuje trám za okapovou vaznici, teoreticky by se ale mohlo jednat i o základ nadzemní stěny rámové konstrukce. Podle našeho názoru jsou nápadné ještě třri další situace signalizující možnou integraci velmi malých zahloubených prostor v nadzemním domu. Bezprostředně před objektem 6F/O3 (s vydřevenou šikmou padačkou - sklepním okénkem či skluzem) se nachází k zemnici orientovaná obdélná pec $6 \mathrm{~F} / \mathrm{O} 6$, podobné jinde signalizovaly př́ítomnost nadzemní stavby. Další takovou dvojicí jsou zemnice 5G/O1 a nadzemní dům s pecí 5G/O2 (Schwabenicky 2009, 48-51). Oba sousedící a shodně orientované objekty mají místy propálenou podlahu. Ve spodní části zásypu zemnice ležela vrstva uhlíků a nad ní vrstva mazanice. Nelze tedy vyloučit, že se jedná o vyhořelý nadzemní dům se sklepem. Obdobně je tomu s objekty 5D/O1 a 5D/O2, kde v zemnici prohořel základový trám a $\mathrm{v}$ dolní části zásypu se nacházela mazanice $\mathrm{s}$ otisky kuláčů (Schwabenicky 2009, 52-54).

Nověji publikoval z tohoto hornického sídliště Kenzler další typ zahloubené stavby o výměře 3,3 $\times 3,8 \mathrm{~m}$, ale zahloubené méně než $1 \mathrm{~m}$. Odlišovala se též stupňovitou úpravou dna se 

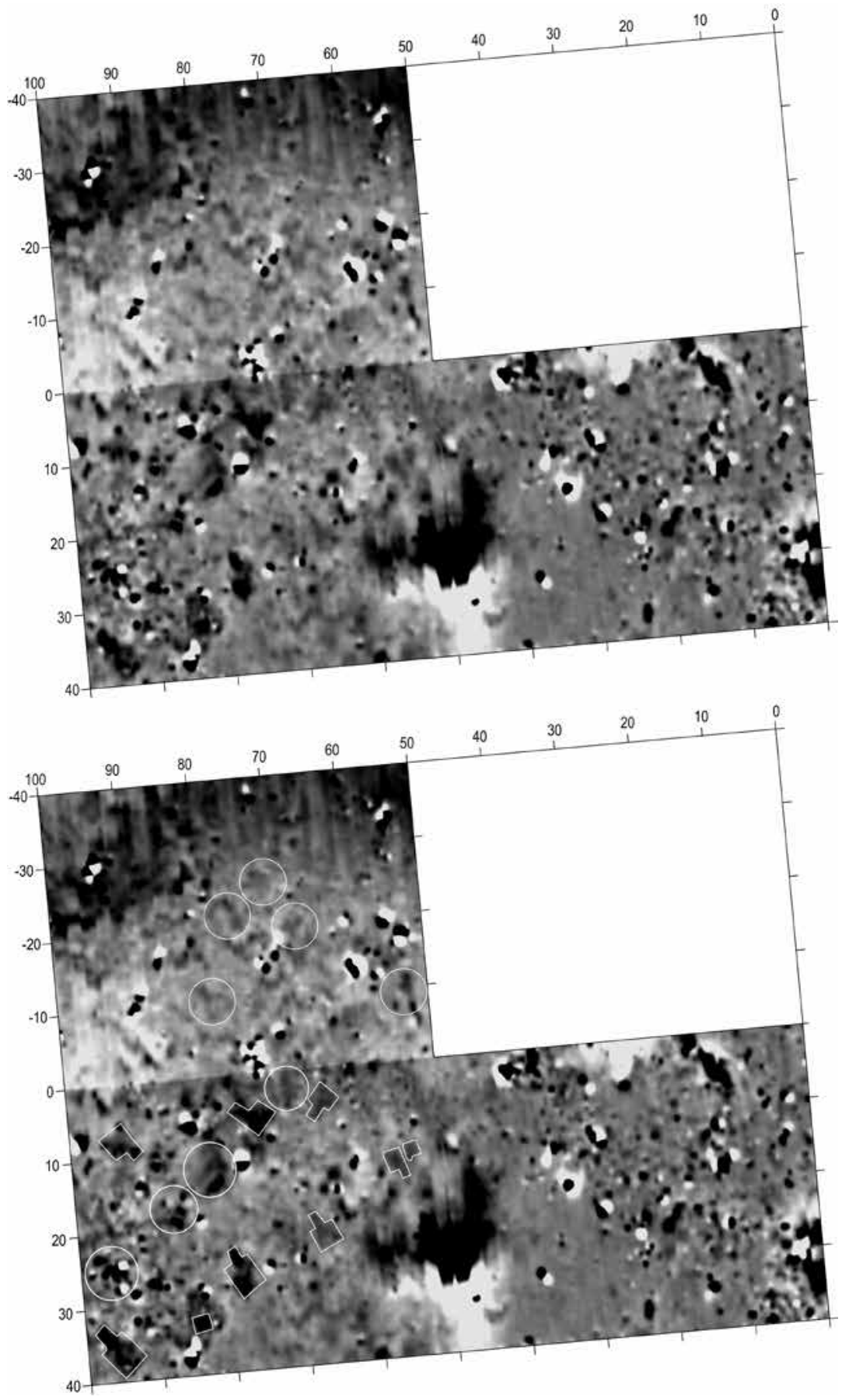

Obr. 4. Cvilínek. Geomagnetické anomálie na svahu v jihozápadní části areálu. S opatrností je lze interpretovat jako relikty staveb. Měření Peter Milo, ÚAM FF MU.

Abb. 4. Cvilínek. Geomagnetische Anomalien am Hang im südwestlichen Teil des Areals, die mit Vorsicht als Gebäuderelikte interpretiert werden können. Vermessung Peter Milo, Institut für Archäologie und Museologie der Phil. Fak. Der Masaryk-Universität. 


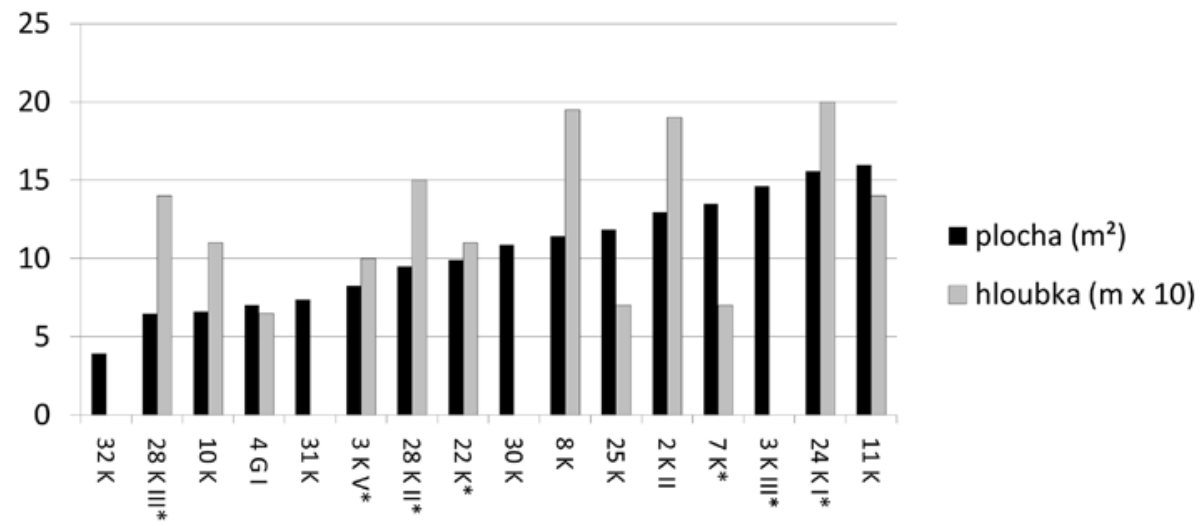

Obr. 5. Rozměry zahloubených staveb na sídlišti Altenberg. * - domy se stopami možných nadzemních pater; K - sklepy; G - údajná zemnice. Autor K. Derner podle Lobbedey 1998.

Abb. 5. Abmessungen der eingetieften Bauten auf dem Altenberg. * - Häuser mit Spuren möglicher oberirdischer Stockwerke; K - Keller; G - angebliches Grubenhaus. Erstellt von K. Derner nach Lobbedey 1998.

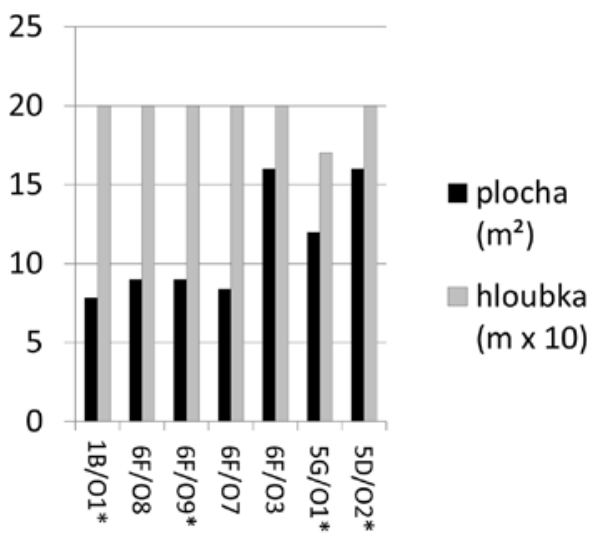

Obr. 6. Rozměry zahloubených staveb na lokalitě Treppenhauer. * - domy se stopami možných nadzemních pater. Stavba 6F/O8 sestávala ze dvou místností uvedených rozměrů. Autor K. Derner podle Schwabenicky 2009.

Abb. 6. Abmessungen der eingetieften Bauten auf dem Altenberg. * - Häuser mit Spuren möglicher oberirdischer Stockwerke. Bau 6F/O8 bestand aus zwei Räumen mit den aufgeführten Abmessungen. Erstellt von K. Derner nach Schwabenicky 2009.

(s destruovanou pecí), část další byla odkryta v Kaufhausgasse 4 (Richter 1995, 6, 30).

Na hornickém sídlišti v Dippoldiswalde byly identifikovány dvě zahloubené stavby se vstupními šíjemi. Hluboké byly přibližně $1 \mathrm{~m}$, plocha činila 11,2, resp. 13,3 $\mathrm{m}^{2}$. Podlahový horizont nebyl vyvinut, otopné zařízení nebylo nalezeno (Wegner-Schubert 2015, 213-215, Abb. 10-15). Pro současné saské montánní archeologické bádání je charakteristické, že obytná funkce těchto „zemnic“" není nijak komentována.

V Čechách došlo k prvnímu nálezu hornické zahloubené stavby u kostela Všech Svatých na sídlišti ztotožňovaném s osadou Antiqua Cuthna. V polozemnici byla naleznena pec s jílovitou kupolí (Valentová 1999, 18). V peci ležely tzv. kutnohorské poháry, které by snad mohly být i technickou keramikou. 


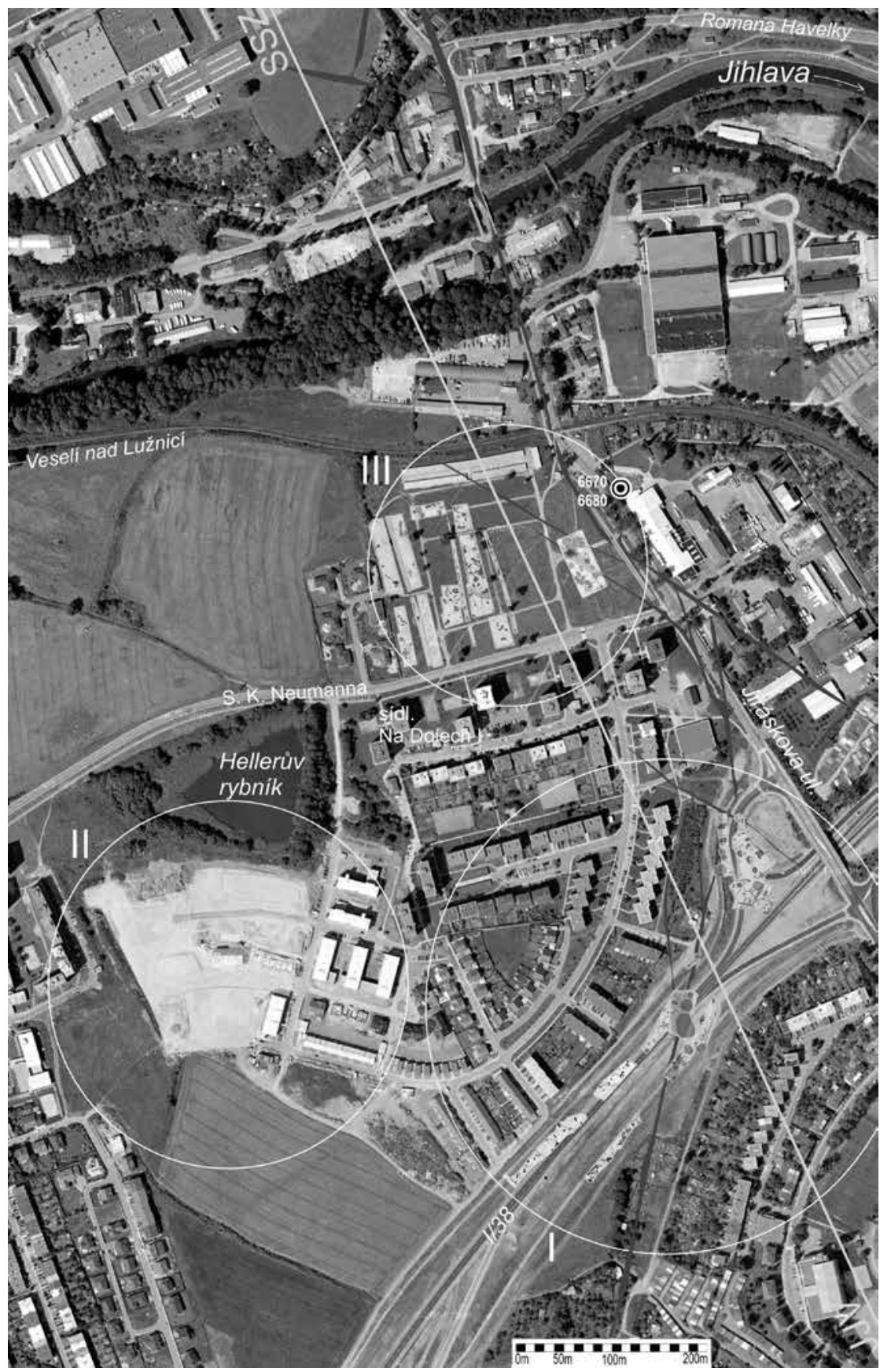

Obr. 7. Ortofotomapa západního okraje Jihlavy s vyznačením archeologicky zkoumaných částí středověké hornické aglomerace, rozvinuté podél starohorské dislokace. $V$ severovýchodní části vynesena poloha pozůstatku zahloubeného obydlí 6669/6670, zkoumaného v roce 2014. Autor P. Hrubý.

Abb. 7. Orthofotokarte des Westrandes von Jihlava mit Kennzeichnung der archäologisch untersuchten Teile der entlang der Dislozierung von Staré Hory entfalteten mittelalterlichen Bergbauagglomeration. Im nordöstlichen Teil eingetragene Lage des im Jahr 2014 untersuchten Überrestes der eingetieften Behausung 6669/6670. Autor P. Hrubý. 


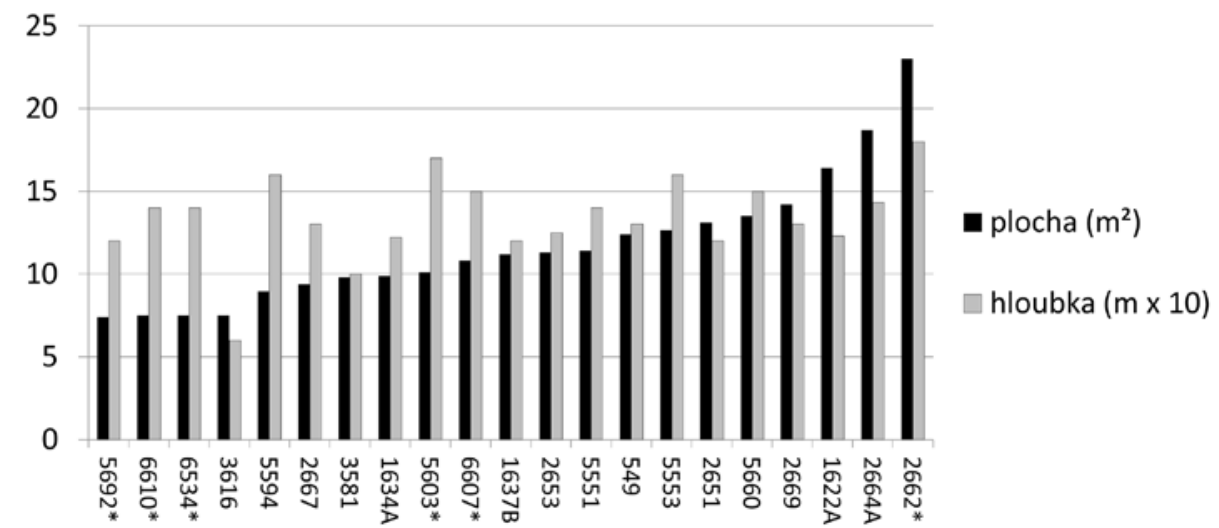

Obr. 8. Rozměry zahloubených staveb na Starých Horách. * - domy se stopami možných nadzemních pater. Autor K. Derner podle Hrubý 2011.

Abb. 8. Abmessungen der eingetieften Bauten auf Staré Hory. * - Häuser mit Spuren möglicher oberirdischer Stockwerke. Erstellt von K. Derner nach Hrubý 2011.
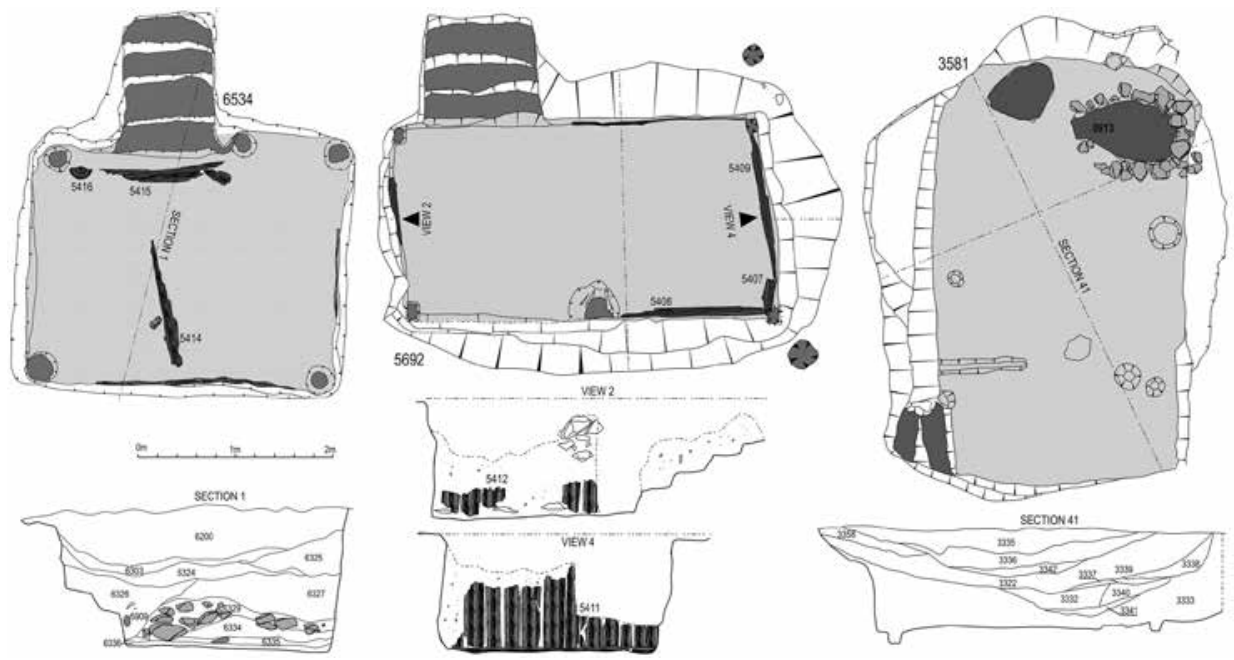

Obr. 9. Relikty středověkých hornických staveb zkoumané na starohorské dislokaci v Jihlavě. Podle Hrubý 2011, 172, 174 a 175. Archeologické výzkumy Archaia Brno.

Abb. 9. Relikte von an der Dislozierung von Staré Hory in Jihlava untersuchten mittelalterlichen Bergbaugebäuden. Nach Hrubý 2011, 172, 174 und 175. Archäologische Grabungen Archaia Brno.

Velmi početný je soubor zkoumaných zahloubených staveb na hornických sídlištích Českomoravské vrchoviny. Jen výzkumy na jihlavských Starých Horách v letech 2002-2006 a 20142015 přinesly doklady téměř tř́ desítek zahloubených staveb (obr. 7, 8).

Většina podzemních částí jihlavských hornických staveb byla doplněna vstupní šíjí. Podlažní úroveň měla většinou charakter tenké vrstvičky bohaté na popel, uhlíky a v některých př́ípadech na zetlelou dřevitou hmotu. Tento stav neumožňuje bezpečně rozpoznat, zda podlahy byly holé, nebo zda byly tvořeny např́íklad deskami (prkny).

$\mathrm{V}$ podlažní úrovni staveb nacházíme $\mathrm{v}$ rozích pravidelné jámy po nosných dřevěných sloupech. Vedle usazení sloupů do jam v rozích se může vyskytnout i usazení na podkladové 


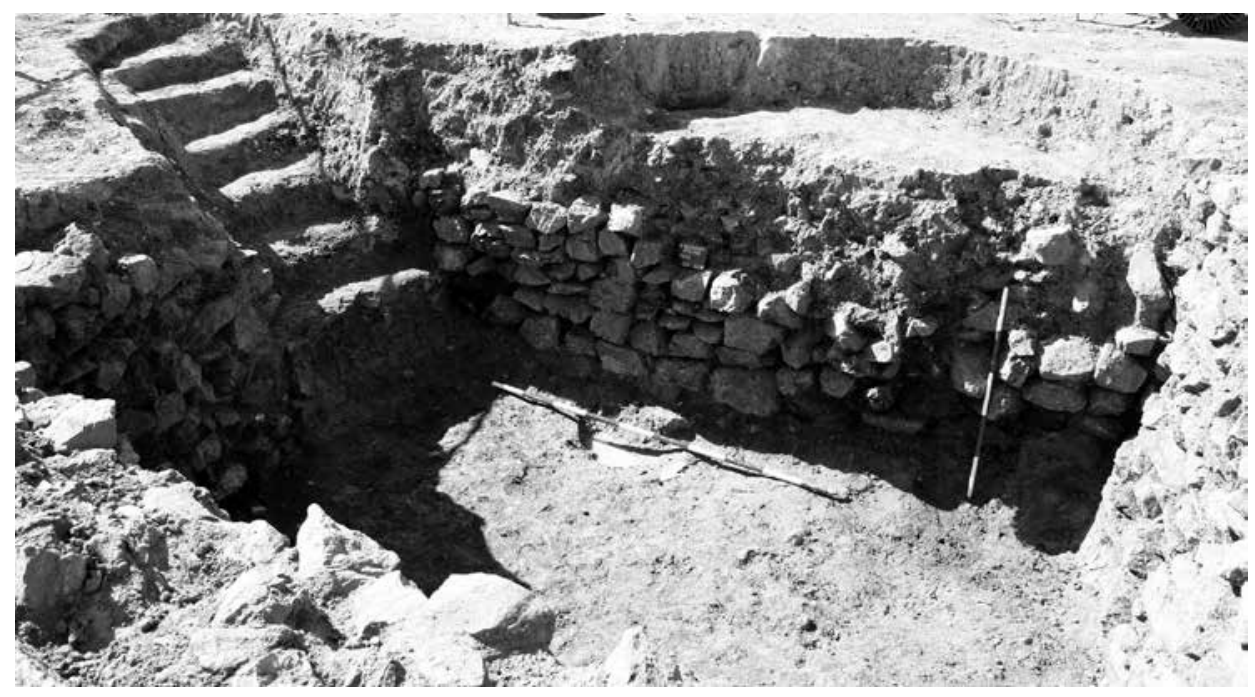

Obr. 10. Jihlava - starohorská hornická aglomerace. Relikt zděné zahloubené části hornické stavby. Podle Hrubý 2011 , 167 a 169. Archeologické výzkumy Archaia Brno.

Abb. 10. Jihlava - Bergbauagglomeration Staré Hory. Relikt des eingetieften Teils eines gemauerten Bergbaugebäudes. Nach Hrubý 2011, 167 und 169. Archäologische Grabungen Archaia Brno.

kamenné plotny, které sloupové jámy nahrazovaly. Zabraňovalo se tak sesedání konstrukce a pravděpodobně i vlhnutí a hnití sloupů odspoda. Kromě základní čtveřice jam v rozích se zde nacházely i stopy sloupů menšího průměru, většinou v polovině délky stěny a u vstupní šíje, což může být pozůstatek dveřního rámu. Jindy byly v podlažní úrovni nalezeny vodorovně uložené hranoly tvořící základní rám konstrukce sklepa. Vazba s rohovými sloupy nebyla archeologicky doložena přímo, dá se ale předpokládat provázání čepováním, sroubením nebo na drážku. Další jsou svisle ukotvené desky na stěnách mezi spodním a horním vodorovným rámem z hranolů. Desky šířek 14-24 cm byly umístěny na vnější straně hranolů. Mohly být upevněny v drážce dlabané středem hranolů (obr. 9).

Jediný suterén byl zděný. Po odebrání kamenné konstrukce nebyly zachyceny žádné doklady kůlových konstrukcí, které by této kamenné konstrukci chronologicky předcházely, takže stavba byla již od počátku koncipována jako dům s kamenným jádrem (obr. 10). Další variantou užití kamene je plenta doplňující dřevohliněnou konstrukci, což bylo na Starých Horách pozorováno v průčelí dvou suterénů vedle vstupní šíje. Situace se podobala suterénu 17/1 na sídlišti Sekanka (Richter 1982, obr. 21 na s. 33). Zajímavou variantou technického řešení statiky starohorských staveb byly podkladové ploché kameny pod nosné sloupové jámy v rozích jednoho ze suterénů (Hrubý 2011, obr. 175 na s. 159, obr. 178 na s. 160).

Masivní výskyty mazanic, popř́ípadě výrazná a mocná požárová vrstva, ve výplních čtyř starohorských staveb naznačují existenci nadzemních částí, které padly za obět' požáru. Značné rozšíření otisků kuláčů průměrů $10-19 \mathrm{~cm}$ ukazuje, že u řady staveb nutno počítat i se sruby, popř́ípadě jinými typy konstrukcí. Upřednostněný výběr rovného dřeva tohoto průměru byl podmíněn možnostmi dopravy, cenovou dostupností a nejspíš i náročností dopravy, tesařského zpracování, usazování a zdvihání do výšky při stavbě stropů a krovů. Kuláče, a to nejpravděpodobněji právě ze zrríceného stropu, byly ostatně nalezeny v suterénu vícedílné a požárem zachvácené stavby v severní části aglomerace v roce 2014 (obr. 11:1 a obr. 12).

Naše znalosti doplňuje odkryv torza složitější stavby v severní části tzv. Starohorského couku v roce 2014 (Hrubý 2015; zde obr. 7). Jejím základem byla obdélná konstrukce s jámami 

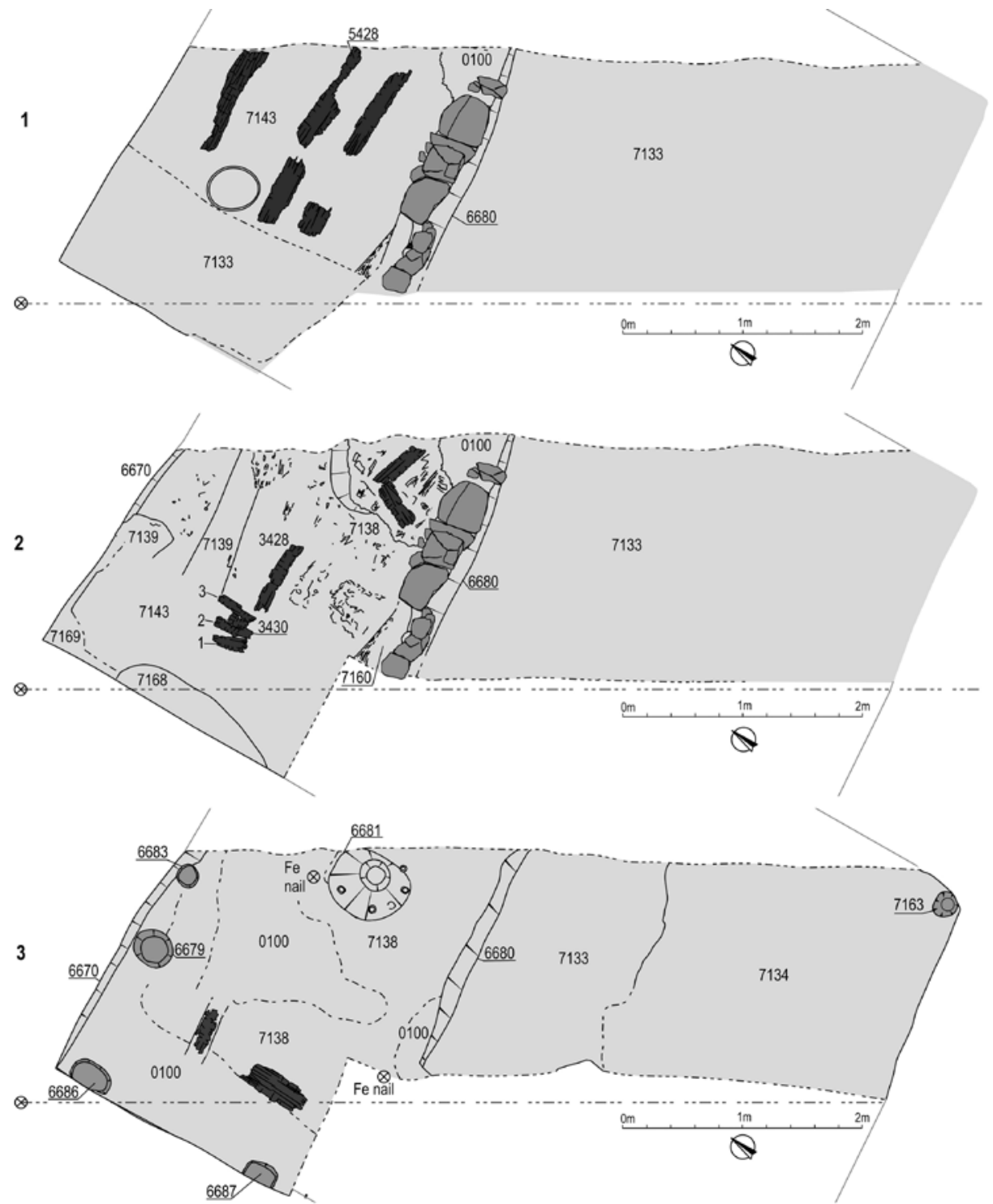

Obr. 11. Jihlava - starohorská hornická aglomerace. Relikt členěné zahloubené části hornické stavby 6669/6670. Zobrazeny jsou tři fáze odkryvu. Podle Hrubý 2015. Archeologické výzkumy Archaia Brno.

Abb. 11. Jihlava - Bergbauagglomeration Staré Hory. Relikt des gegliederten eingetieften Teils des Bergbaugebäudes 6669/6670. Dargestellt werden die drei Freilegungsphasen. Nach Hrubý 2015. Archäologische Grabungen Archaia Brno.

pro rohové nosné sloupy a další sloupky podél stěn. Struktura byla výjimečná vnitřním členěním přičkou s kamennou podezdívkou, kdy u každé z takto vzniklých místností byl v niveletě podlahy rozdíl 15 až $20 \mathrm{~cm}$ (obr 13-15). Rozměr suterénní části stavby lze odhadnout na $5 \times 6 \mathrm{~m}$, hloubka od původního povrchu byla v rozmezí 1,2 až $1,5 \mathrm{~m}$. V interiéru byly patrné stopy požáru, které však pozorujeme jen v severní části (obr. 12). Shořelá jedlová dřeva uložená v jednotné niveletě a $\mathrm{v}$ pravidelných rozestupech rovnoběžně vedle sebe nabízí představu záklopového stropu 


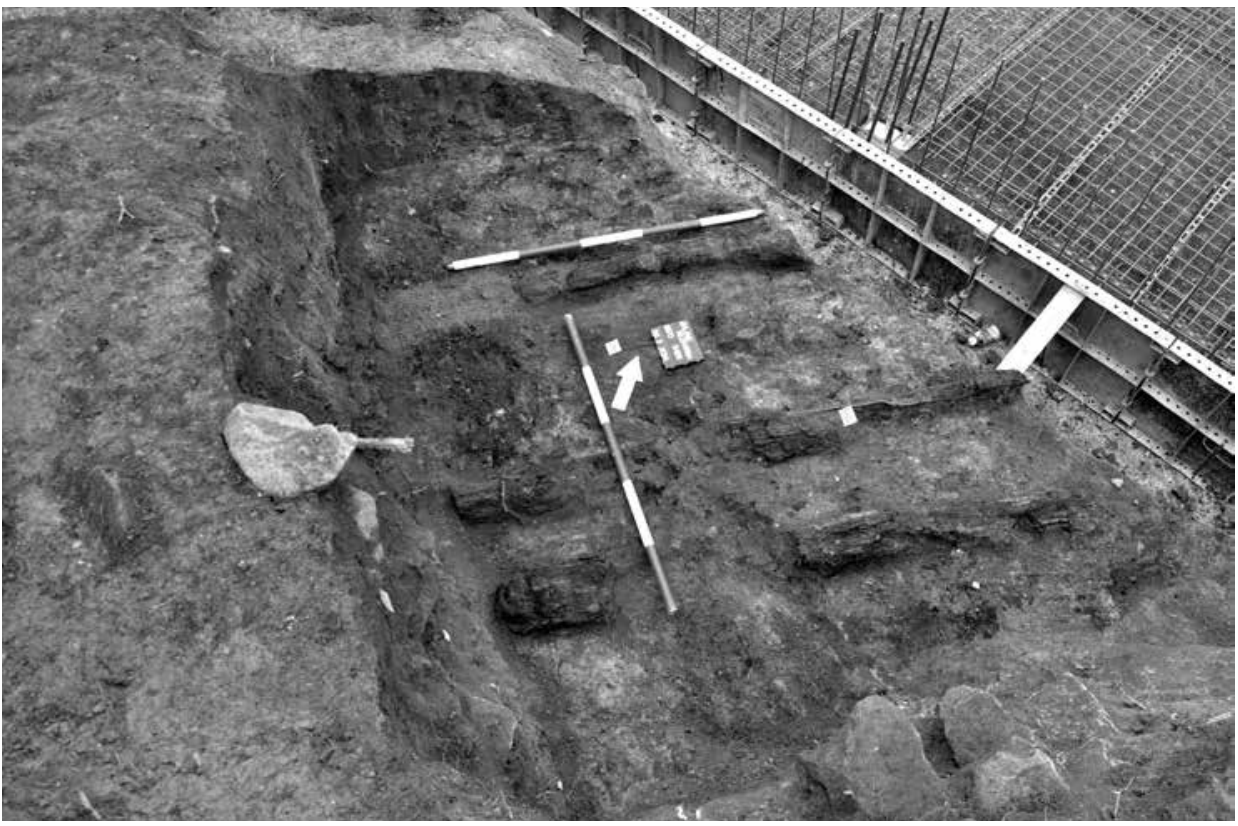

Obr. 12. Jihlava - starohorská hornická aglomerace. Relikt členěné zahloubené části hornické stavby 6669/6670. Na snímku severní část stavby se shořelými kuláči, považovanými za zhroucený strop. Podle Hrubý 2015. Archeologické výzkumy Archaia Brno.

Abb. 12. Jihlava - Bergbauagglomeration Staré Hory. Relikt des gegliederten eingetieften Teils des Bergbaugebäudes 6669/6670. Auf der Aufnahme nördlicher Teil des Baus mit verbrannten Rundhölzern, die als eingestürzte Decke angesehen werden. Nach Hrubý 2015. Archäologische Grabungen Archaia Brno.

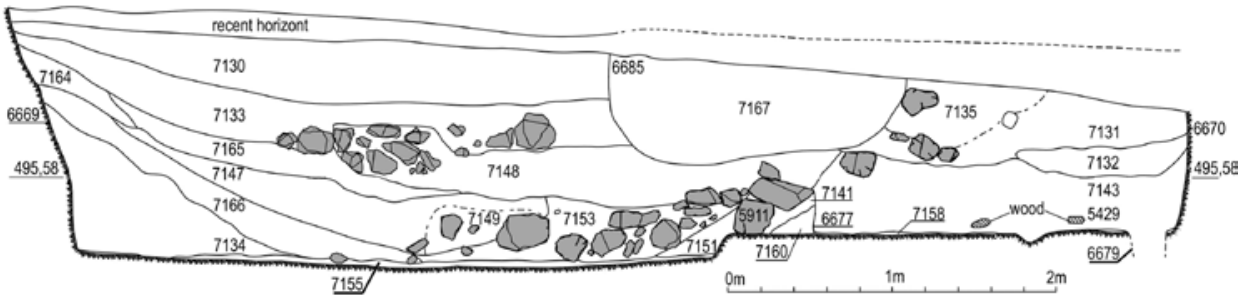

Obr. 13. Jihlava - starohorská hornická aglomerace. Řez členěnou zahloubenou částí hornické stavby 6669/6670. Podle Hrubý 2015. Archeologické výzkumy Archaia Brno.

Abb. 13. Jihlava - Bergbauagglomeration Staré Hory. Schnitt durch den gegliederten Teil des Bergbaugebäudes 6669/6670. Nach Hrubý 2015. Archäologische Grabungen Archaia Brno.

(obr. 16). Smýcení jednoho z těchto dřevěných prvků (č. 3428, obr. 11:3) bylo dendrochronologicky stanoveno do zimy 1247/1248 (Kyncl 2014).

Kriticky je samozřejmě třeba brát v potaz možnost, že nemusí jít o jednu dvojdílnou stavbu, nýbrž o superpozici dvou staveb, které na sebe chronologicky navazují a z nichž ta starší zanikla požárem. Nezdá se ovšem příliš pravděpodobné, že by mladší stavba vznikla v místě té předcházející a přitom velmi presně navázala na původní půdorys.

Zániková stratigrafie hovoří jasně snad jen v tom smyslu, že v jižní části (s nižší úrovní podlahy) byly odstraněny destrukční požárové vrstvy, dochované jen v severní mělčí a menší 
místnosti (obr. 13). Př́ípustná je tak i varianta, že jde o dvouprostorovou stavbu, postavenou po roce 1248. Někdy po polovině 13. století zanikla požárem, přičemž stratigrafie v jižní části stavby naznačuje obnovu stavby ve zmenšeném plošném rozsahu. Poměrně homogenní keramický soubor z obou prostorových a stratigrafických kontextů ani další kategorie nálezů žádné jasnější chronologické závěry neumožňují (obr. 17-20).

Z dalších hornických lokalit Českomoravské vrchoviny je třeba zmínit nálezy z katastru České Bělé, trati V Jamách, kde byly odkryty dva neobvykle malé půdorysy. Zahloubenou prostoru o rozměrech $2 \times 1,8 \mathrm{~m}$ se schodovitou úpravou dna a druhou se zanedbatelnou hloubkou okolo $30 \mathrm{~cm}$ lze spíše spojovat s pracovní činností než s obýváním (Hrubý a kol. 2014, 78). Na hornickém sídlišti Cvilínek byly plošně zkoumány pozůstatky čtyř zahloubených staveb dřevohliněné konstrukce (Hrubý a kol. 2012). Jedna měla dobře zachovanou a jedna nejistou destruovanou - pec napravo od vstupu. Ve druhé ze zmíněných staveb byla nalezena i sada snad technické keramiky, což může naznačovat, že dům nesloužil výhradně obytným účelům.

Od roku 2012 do roku 2018 prováděl v rámci projektu ArchaeoMontan ÚAPP SZČ výzkum hornického sídliště Kremsiger u Př́ísečnice v Krušných horách (Derner 2018). Sídliště vzniklo patrně ve třetí třetině 13 . století a zaniklo kolem poloviny 14. století. V terénu je patrných 45 sníženin interpretovaných jako pozůstatky zahloubených částí domů (obr. 2). Odkryvem byly zkoumány tři z nich.

Zahloubená část domu III, zkoumaného sítí sond, měla rozměry $4,2 \times 5 \mathrm{~m}$ a hloubku do $2,2 \mathrm{~m}$ pod původním povrchem (obr. 21-23). Součástí byla vstupní rampa šířky přibližně $1,1 \mathrm{~m}$. Na dně se zachoval základový věnec trámů a v nižších partiích zásypu jeden svislý trám rámové konstrukce stěn. U středu interiéru se nacházela dvojice mělkých pravoúhlých sloupových jamek. Podlaha byla tvořena nízkým jílovitým nášlapem s několika kumulacemi uhlíků. V jižním rohu se nacházela kupa propálené hlíny s kameny. Mohlo by se jednat o pec propadlou z vyššího patra. Ve střední úrovni zásypu se nacházela maximálně $15 \mathrm{~cm}$ silná vrstva s nesouvislými proplástky propálené hlíny a výše mocný kamenný zával. Ten mohl pocházet ze sesuté nasucho kladené podezdívky vně okrajů jámy. Na ní by spočívaly okapové vaznice zemnice, či nadzemní patro (obr. 24). Západně od zahloubené části byla dokumentována na sucho kladenou zídkou obezděná terasa o rozměrech přibližně $10 \times 7 \mathrm{~m}$. Na terase se jižně od vstupní rampy nacházela kruhová kamenná pec. Variantu, že by zde stála přední nadzemní část domu, do nějž by byla zahloubená část integrována jako sklep, spíše vylučujeme, nebot’ terasa je mírně skloněná $\mathrm{k}$ jihu a dále vstupní š́je je zaplněna vrstvami s velmi hojnými nálezy, které by se sem z interiéru domu jen těžko dostávaly. Pravděpodobně byla zaplněna odpadem deponovaným již od počátku vně šíje. Na druhé straně terasa byla prozkoumána jen z malé části, takže prŕípadné stopy nadzemních konstrukcí mohly pozornosti uniknout.

V případě domu XLV byl úzký průkop veden šikmo, takže kolmá vzdálenost stěn zahloubené prostory musela být menší než v sondě naměřených $488 \mathrm{~cm}$ (obr. 25). Do podloží byla v jižní části sondy zahloubena kruhová jamka (vkop 2019) o průměru $86 \mathrm{~cm}$ a hloubce $37 \mathrm{~cm}$, zaplněná až po zániku domu. Mohlo se jednat o drobnou skrýš, jejíž konstrukce a obsah se nedochovaly. Podlaha byla tvořena tenkým nášlapem. Ve výplni stavby je třeba poukázat na spáleništní vrstvu 2009 obsahující drobné zlomky mazanice a velké uhlíky v rozsahu sondy pocházející patrně z jediného shořelého kuláče. Nelze rozhodnout, zda pocházela z nadzemní konstrukce podsklepeného domu, štítu zemnice, či stavby situované před vstupní šijí, odkud se vrstvy výplně do zahloubené prostory svažovaly.

Jako dům X byla označena rozměrná sníženina bez viditelné vstupní šíje na severním okraji pravidelné části sídliště (obr. 26). Z výsledků sondáže kř́ížovým průkopem vyplývá, že se původně jednalo o impozantní zahloubenou dvojdílnou prostoru s místnostmi o nestejné hloubce (obr. 27). Západní část byla dlouhá $10 \mathrm{~m}$, východní $6,25 \mathrm{~m}$. Šířka západní části je $5,06 \mathrm{~m}$ a šířka východní části byla asi obdobná. Hloubka výkopu západní části dosahovala až 2,66 m pod současným terénem, východní části $2,46 \mathrm{~m}$. Dno východní místnosti leželo $35 \mathrm{~cm}$ pod úrovní dna západní prostory. Horní okraj takto vzniklého stupně byl zpevněn kameny. Po obvodu západní místnosti probíhaly základové trámy, u delších stěn ve žlábcích vytesaných do skály. U štítové 

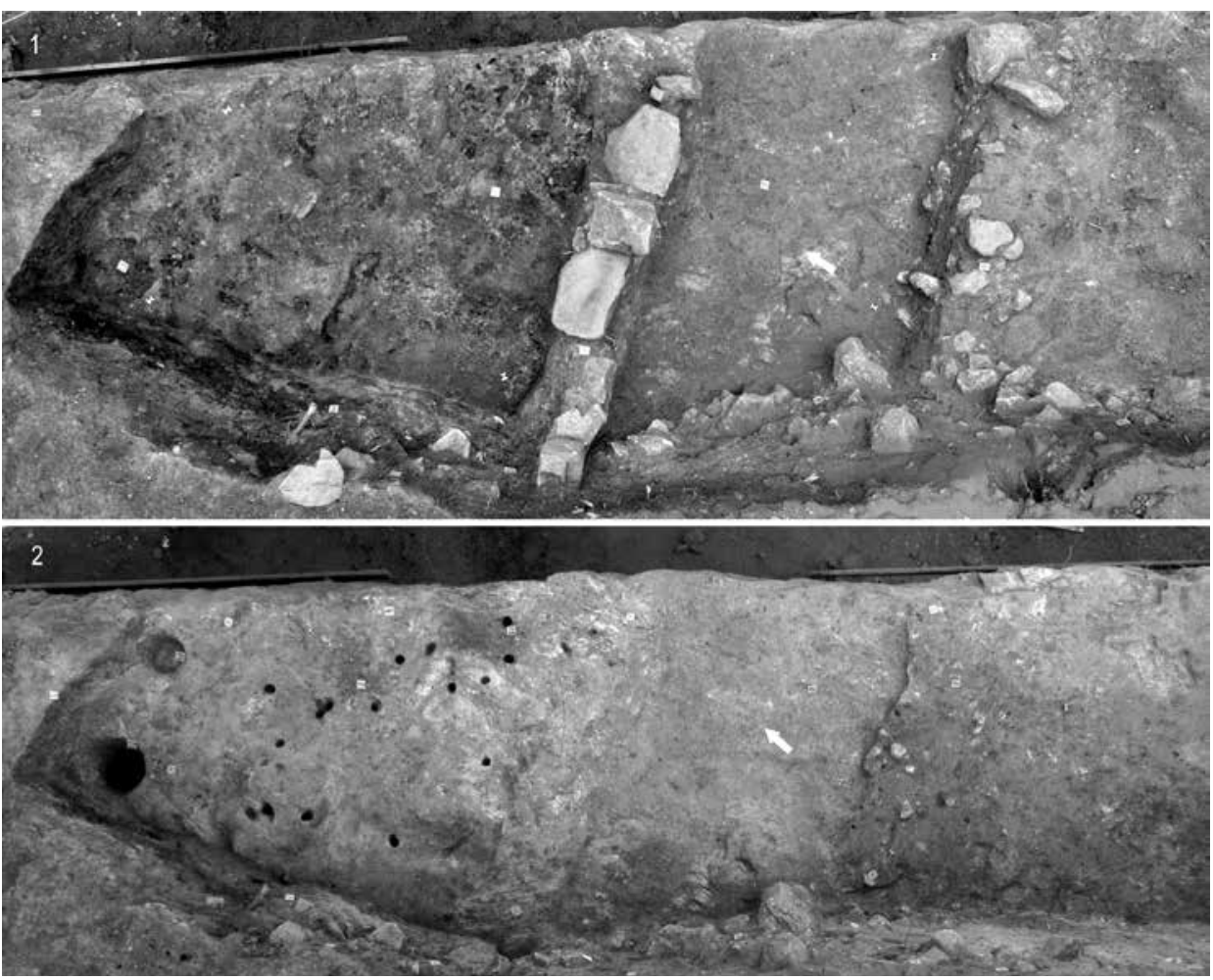

Obr. 14. Jihlava - starohorská hornická aglomerace. Relikt zahloubené vícedílné stavby 6669/6670. Výzkum Archaia Brno 2014. Foto Archaia Brno.

Abb. 14. Jihlava - Bergbauagglomeration Staré Hory. Relikt des eingetieften mehrteiligen Baus 6669/6670. Grabung Archaia Brno 2014. Foto Archaia Brno.

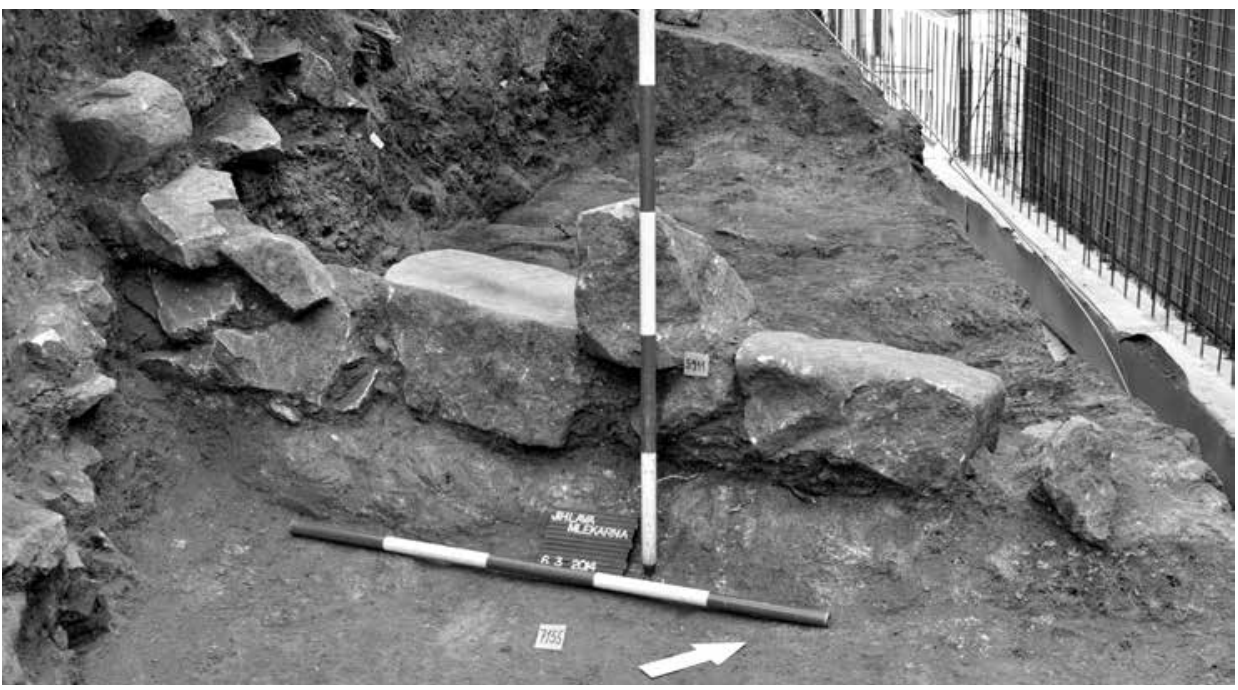

Obr. 15. Jihlava - starohorská hornická aglomerace. Relikt členěné zahloubené části hornické stavby 6669/6670. Detail kamenné podezdívky dělící interiér. Podle Hrubý 2015.

Abb. 15. Jihlava - Bergbauagglomeration Staré Hory. Relikt des gegliederten eingetieften Teils des Bergbaugebäudes 6669/6670. Detail der den Innenraum teilenden Grundmauer. Nach Hrubý 2015. 


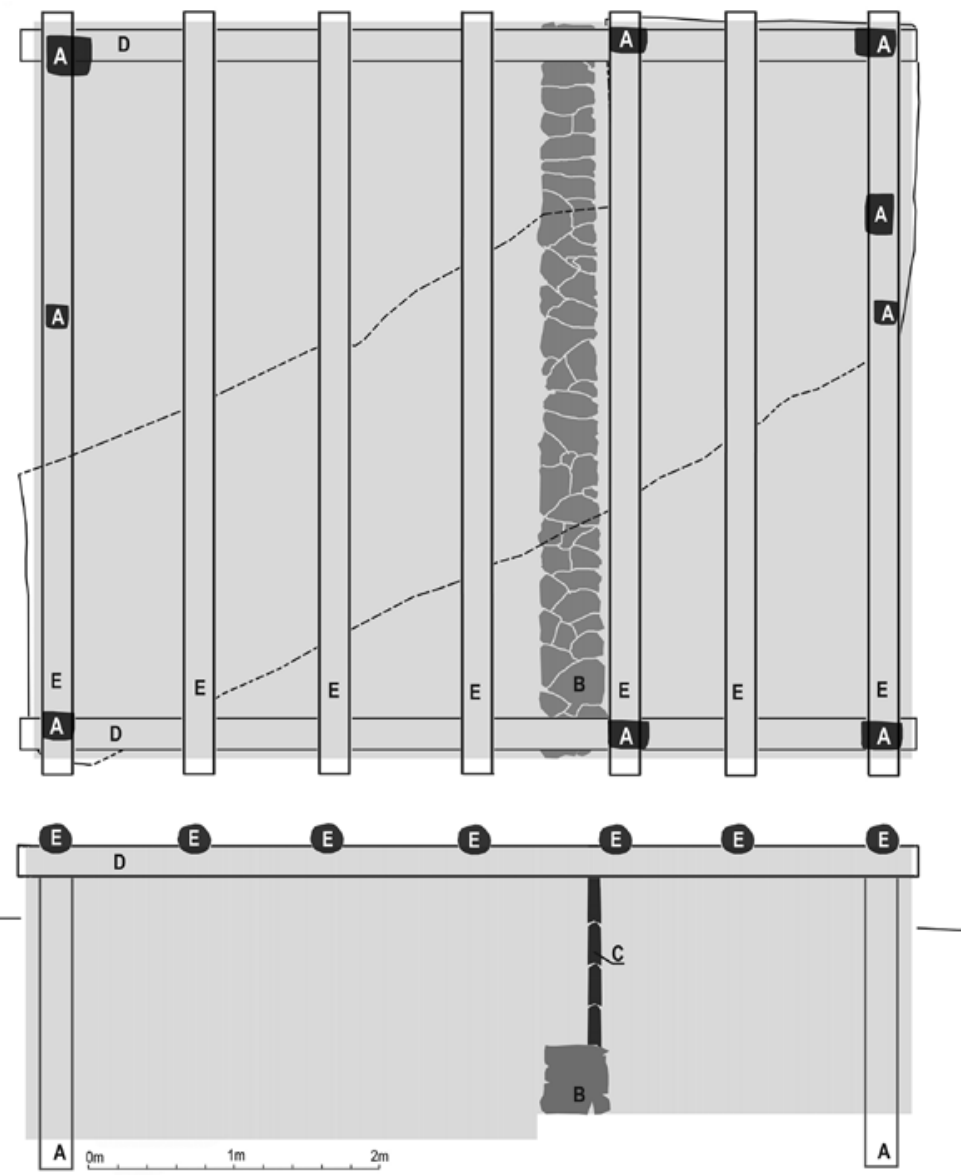

Obr. 16. Jihlava - starohorská hornická aglomerace. Idealizovaná a hypotetická schematická rekonstrukce rozměrů, tvaru a konstrukěních prvkủ suterénní ěásti stavby 6669/6670. A - stojky; $B$ - kamenná podezdívka dělicí přičcy; $C$ - hypotetická př́ička ze štípaných desek; $D$ - podélné ležaté trámy završující suterén; E - stropní kuláče. Podle P. Hrubý.

Abb. 16. Jihlava - Bergbauagglomeration Staré Hory. Idealisierte und hypothetische schematische Rekonstruktion der Maße, der Form und Konstruktionselemente des Souterrainteils von Bau 6669/6670. A - Pfosten; B - Grundmauer der Trennwand; C - hypothetische Trennwand aus gespaltenen Brettern; D - das Souterrain krönende längs liegende Balken; E - Deckenrundhölzer. Nach P. Hrubý.

západní stěny na trám navazovaly pruhy zetlelého dřeva rovnoběžné s touto stěnou. Mohlo by se jednat o spadlou výdřevu stěny, dřevěnou podlahu, či sesutý strop. V tom př́ípadě by horizontálně uložená jílovitá vrstva $8005=9005$ byla jeho izolační omazávkou. Zhruba v ose domu se nacházely dvě sloupové jamky. Ve východní místnosti spočívaly obvodové trámy na stupni vytesaném do skály. Ve skalnatém dně mezi nimi se ještě nacházely tři př́ičné žlábky se zetlelými trámy. Tyto sloužily patrně jako polštáře pro dřevěnou podlahu, vyrovnávající do jisté míry výškový rozdíl obou místností (obr. 28). V úzkém průkopu byly skutečně pozorovány dva delší pruhy dřeva přibližně v ose domu, představující snad pozůstatky podlahy. Užitná plocha (bez obvodových trámů) činila $70 \mathrm{~m}^{2}$. Zásyp obou částí byl odlišný. V západní byl tvořen výhradně kamennou destrukcí, ve východní části složitějším souvrstvím obsahujícím ve střední úrovni 

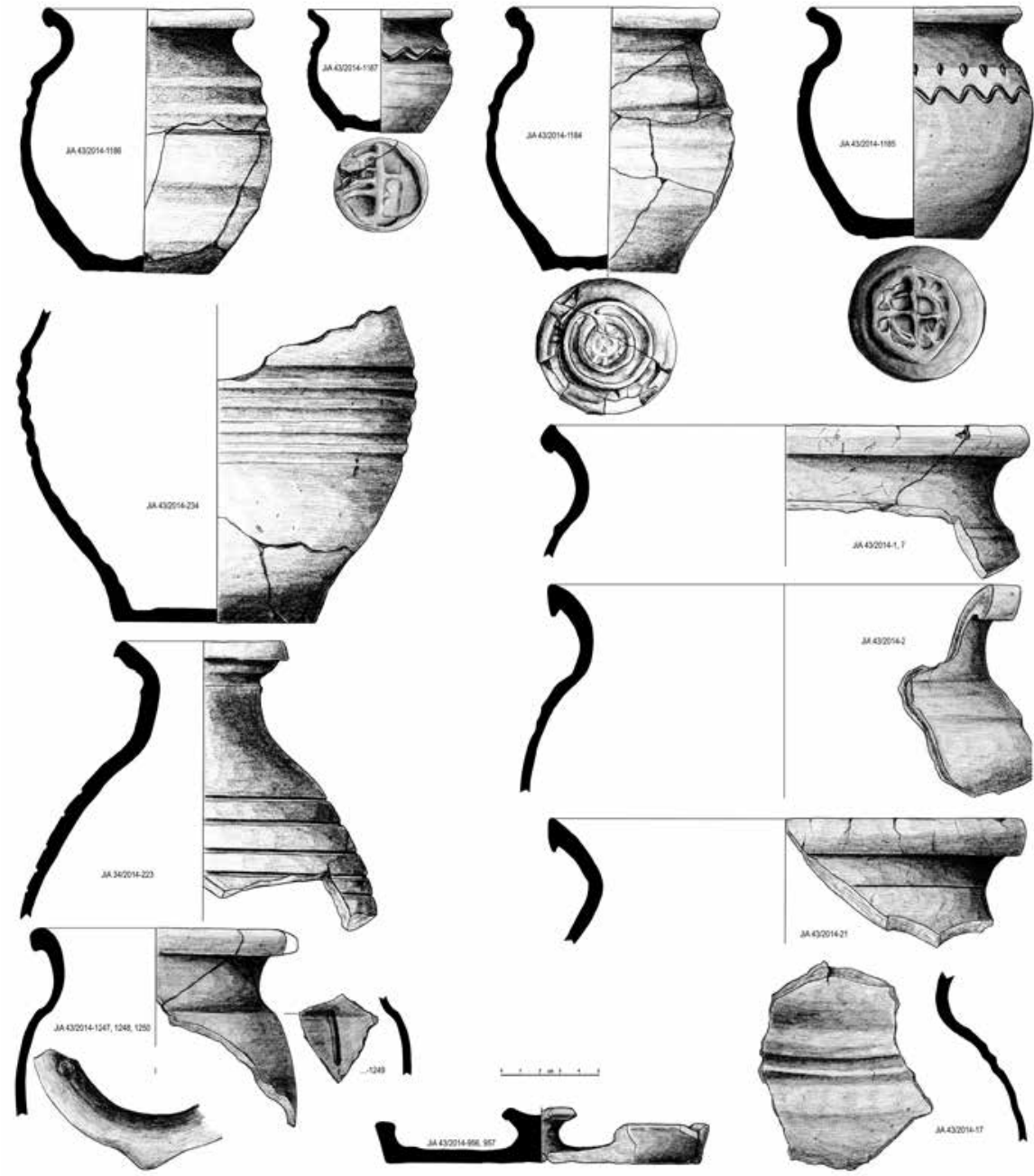

Obr. 17. Jihlava - starohorská hornická aglomerace. Keramika ze zánikových a požárových vrstev ve výplni struktury 6669/6670. Podle Hrubý 2015. Kresba E. Bílková Šamalová.

Abb. 17. Jihlava - Bergbauagglomeration Staré Hory. Keramik aus den Untergangs- und Brandschichten in der Verfüllung von Struktur 6669/6670. Nach Hrubý 2015. Zeichnung E. Bílková Šamalová.

tři vrstvy tvořené slabě propálenou hlínou a v malé míře mazanicí (9008, 9012 a 9013). Objem zásypu východní části byl větší a nedá se odvodit ze splachů okolního terénu.

Zahloubená stavba podobného typu a hlavně rozměrů nemá dosud na hornických sídlištích obdoby. Původní rekonstrukce domu jako zemnice vycházela z předpokladu, že východní zahloubená prostora pro sídliště „normovaného“ rozměru navíc s dřevěnou podlahou byla obytná, zatímco západní byla skladovací. Pravděpodobnější však je, že se jednalo o plochostropý sklep (obr. 29). Nadzemní zdi by pak soudě dle zásypu v západní části byly roubené, či rámové konstrukce na kamenné podezdívce, ve východní patrně celé hrázděné. Se sklepy obdobných dimenzí, dokonce vícedílnými se sice vzácně, ale přeci jen setkáváme v soudobých městech (Holub a kol. 2005, 51, 89-90, obr. 5:11, obr. 6; Küntzel 2009, Tab. 37). O větších dělených sklepech se 
uvažuje jako o prodejních halách. Nedělené bývají dávány do souvislosti se skladováním vína či obecně ekonomickou silou majitele (Küntzel 2009, 187). Podobně na vesnicích bývají (velké) sklepy součástí šenků. Tato interpretace se pro dům X jeví jako nejpravděpodobnější. Povolení šenkovat na hornických sídlištích „pivo, víno a medovinu“ najdeme ostatně i v normativních pramenech (Tomaschek 1897, 66 č. 93).

\section{Průběžná bilance: Jsou na hornických sídlištích častější doklady obytnosti „zemnic“ než ve městech?}

Na dlouhou otázku existuje krátká odpověd': nejsou. Všechny myslitelné ukazatele obytnosti poskytují stejně rozporuplný obraz jako ve městech.

Evidentní otopná zařízení jako pece jsou velmi vzácná a rozhodně nepatřila $\mathrm{k}$ běžnému vybavení zahloubených prostor. Kontrastuje to s podobou otopných zařízení v nadzemních stavbách. Tam, kde jsou v zemnicích pece přítomny, naznačují často doprovodné nálezy jako prubířská keramika či nálezová situace (extrémně malá výměra zahloubené prostory), že se nejedná o běžné otopné zařízení. Ani propálené plochy na podlaze u jinak ohněm nedotčených staveb nebyly zaznamenány. Otázkou je, zda propálené plochy nemohly při výzkumu pozornosti uniknout, nakolik mohla být ohniště přenosná, př́ípadně zničená pozdějšími adaptacemi prostor pro skladovací účely apod. Jedinou spornou indicií topeniště tak zůstávají uhlíky v podlahových vrstvách. Odlišit nášlap od uhlíků z ohniště by vyžadovalo detailní záznam a vyhodnocení nálezové situace pracující s informacemi kde, kolik a jak velkých uhlíků bylo nalezeno. Veškerá starší dokumentace, která toto nezohledňuje, by byla nepoužitelná.

Dalším znakem obytného charakteru by měla být smysluplná využitelná plocha. U zahloubených staveb na hornických sídlištích je v průměru zřetelně menší než u nadzemních (viz výše).

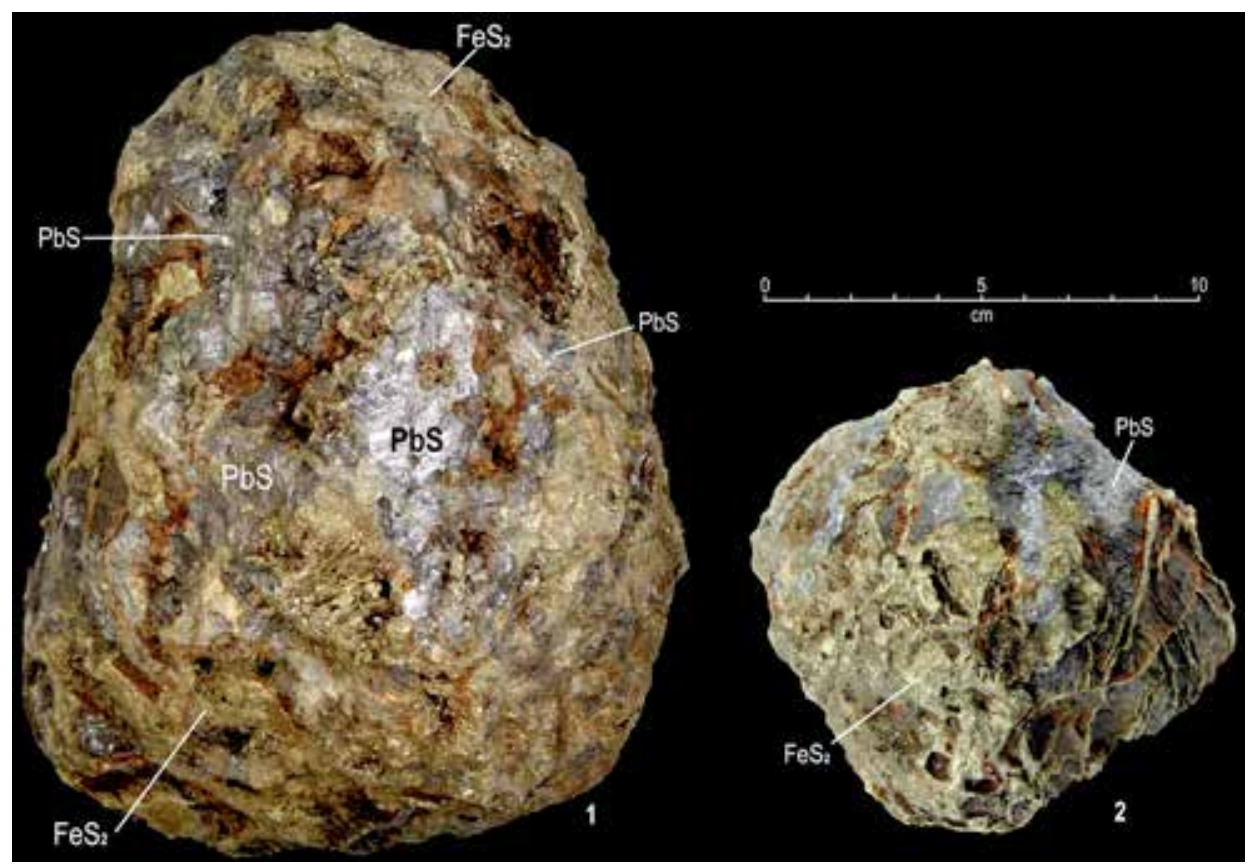

Obr. 18. Jihlava - starohorská hornická aglomerace. Ukázka rudniny nalezené ve svrchních zánikových vrstvách struktury 6669/6670. Foto Archaia Brno.

Abb. 18. Jihlava - Bergbauagglomeration Staré Hory. Beispiel von in den oberen Untergangsschichten von Struktur 6669/6670 gefundenem Roherz. Foto Archaia Brno. 
Navíc mezi jednotlivými stavbami i na jednom sídlišti silně kolísá a na některých sídlištích zahrnuje i zřetelně „,neobytné“ velikosti (obr. 5 a 8 , částečně 6). Orientačním měřítkem obytnosti

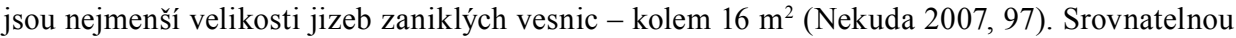
situaci pozorujeme u některých zaniklých měst, např́íklad u Frayensteinu, kde na téměř každé parcele nacházíme zahloubenou prostoru, část z nich jsou ale jednoznačně sklípky (Schenk 2009, Abb. 79 na s. 107). Jako nejjednodušší vysvětlení se nabízí, že i na hornických sídlištích jsou to všechno různě velké sklepy, i když v individuálních př́ípadech nelze jistě krátkodobě některé z nich jako obytná provizoria vyloučit.

Až na výjimky chybí také náročnější úpravy podlah, u kamenných stěn doklady omítek.

\section{Možné rekonstrukce nadzemních částí staveb a eventuální začlenění do organismu nad- zemních domů}

Pro správné vyhodnocení terénních situací (povaha stavebních prvků v zásypech, stopy vnějších konstrukcí) je třeba pracovat s určitými modely vzhledu zahloubených staveb, at' se již mělo jednat o zemnice, nebo sklepy. Dosud navržené rekonstrukce (obr. 30) vycházejí z výsledků výzkumů ve městech (obr. 31). Navržena byla následující řešení: zemnice bez nadzemních konstrukcí, případně s mírně nad terén protaženými stěnami (např. Schwabenicky 2009,
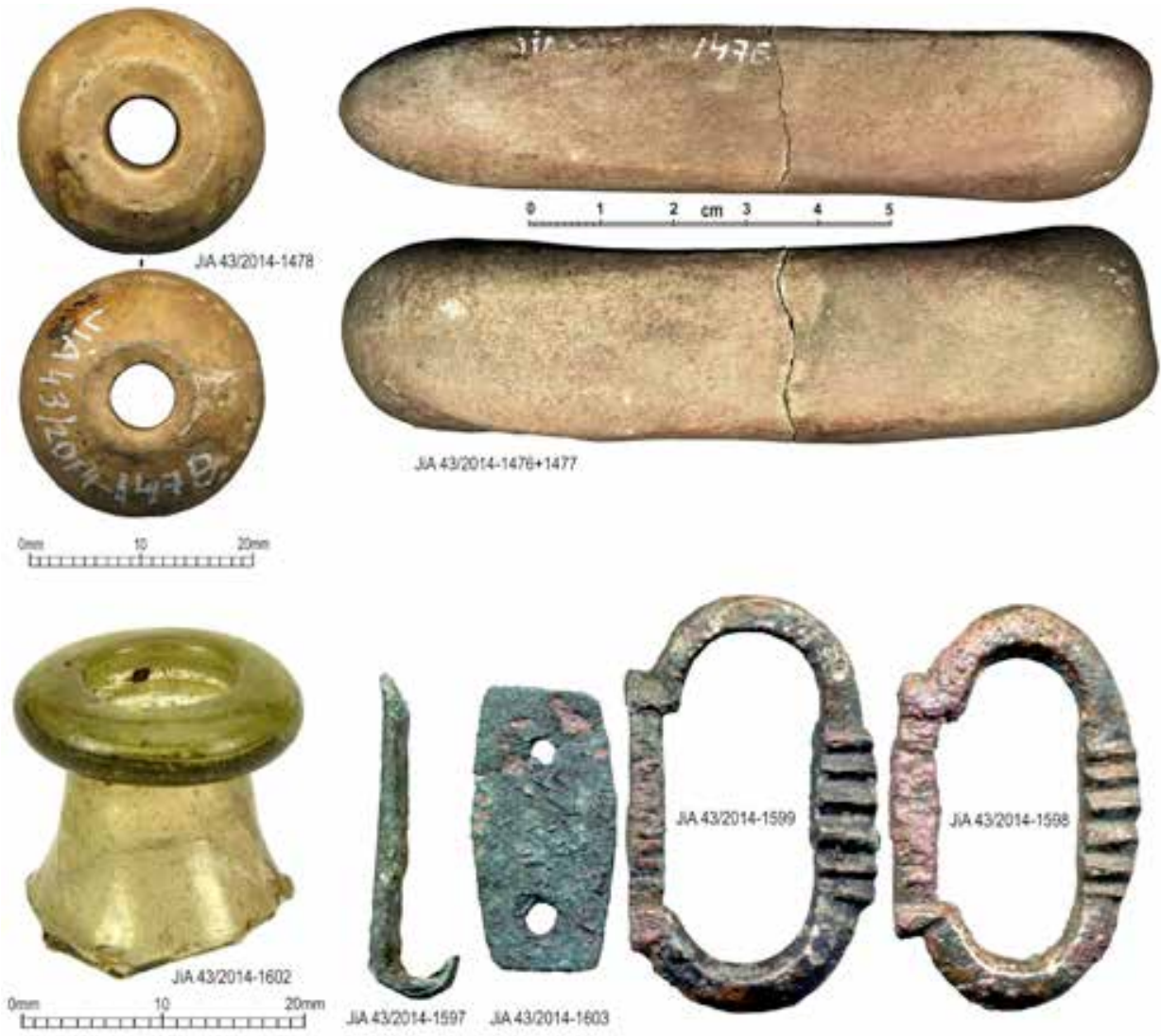

Obr. 19. Jihlava - starohorská hornická aglomerace. Drobná hmotná kultura nalezená v zánikových a požárových vrstvách struktury 6669/6670. Podle Hrubý 2015. Foto P. Duffek a P. Hrubý.

Abb. 19. Jihlava - Bergbauagglomeration Staré Hory. In den Untergangs- und Brandschichten von Struktur 6669/6670 gefundene kleine Sachkultur. Nach Hrubý 2015. Foto P. Duffek und P. Hrubý. 

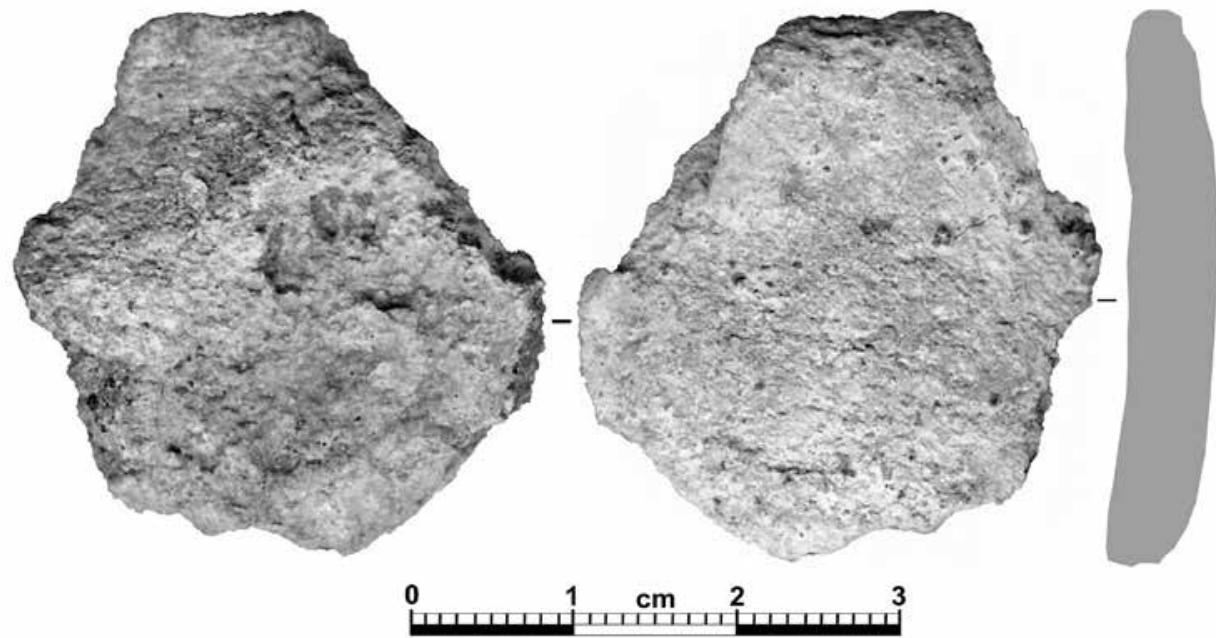

Obr. 20. Jihlava - starohorská hornická aglomerace. Zlomek klejtu ze zánikových a požárových vrstev struktury 6669/6670. Podle Hrubý 2015. Foto P. Hrubý.

Abb. 20. Jihlava - Bergbauagglomeration Staré Hory. Bleiglättenfragment aus den Untergangs- und Brandschichten von Struktur 6669/6670. Nach Hrubý 2015. Foto P. Hrubý.

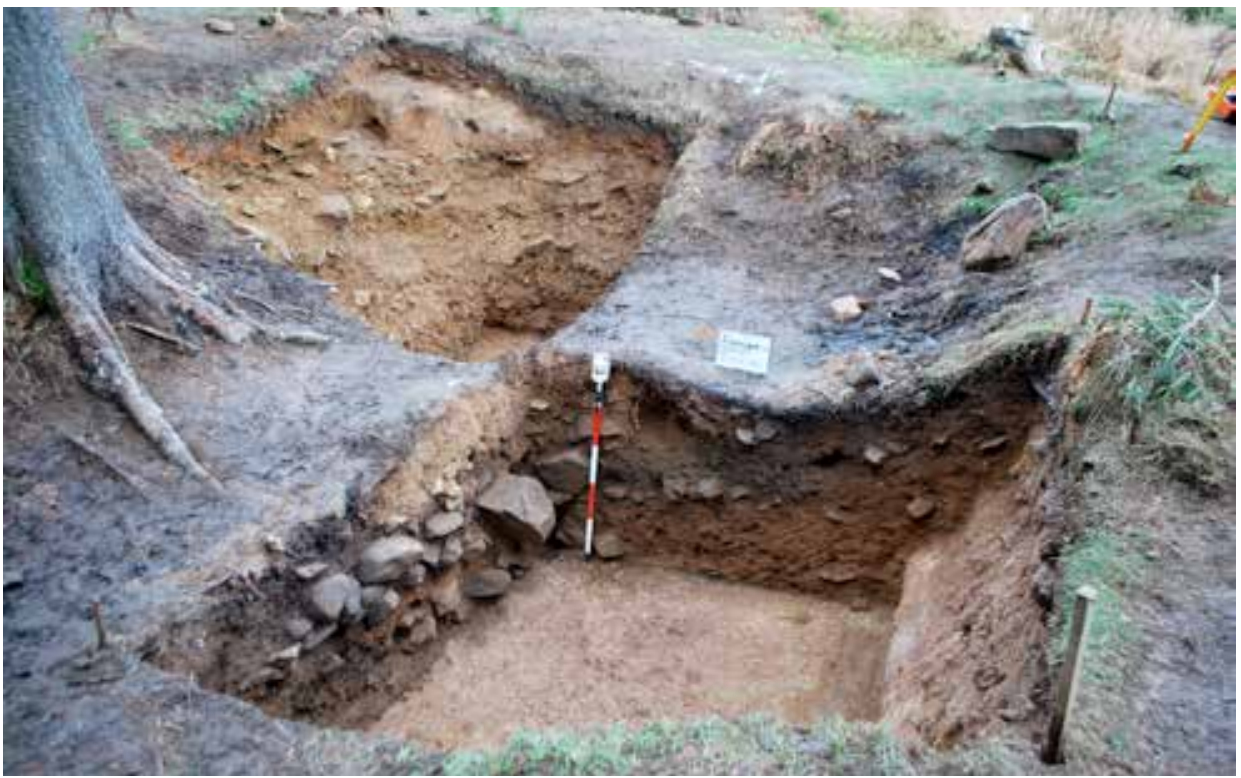

Obr. 21. Kremsiger. Výzkum interiéru domu III. Podle Derner 2018.

Abb. 21. Kremsiger. Grabung im Innenraum von Haus III. Nach Derner 2018.

Abb. 421-423); zemnice s utěsněným stropem zahloubené dýmné jizby - př́ípadně ve formě tzv. dvoupláštové střechy v podobě roubené klenby vystupující nad okolní terén (Velímský 1991, 18; Derner 2015, 116, Fig. 9); přízemní či patrový nadzemní dům, jehož nadzemní stěny jsou pokračováním stěn suterénu (Lobbedey 1998, 26-27; Rieger 2012, 137-138, Abb. 15-16); velký nadzemní dům, který překrývá sklep (Schenk 2009, Abb. 79 na s. 139; Stephan 2010, 248-250, 


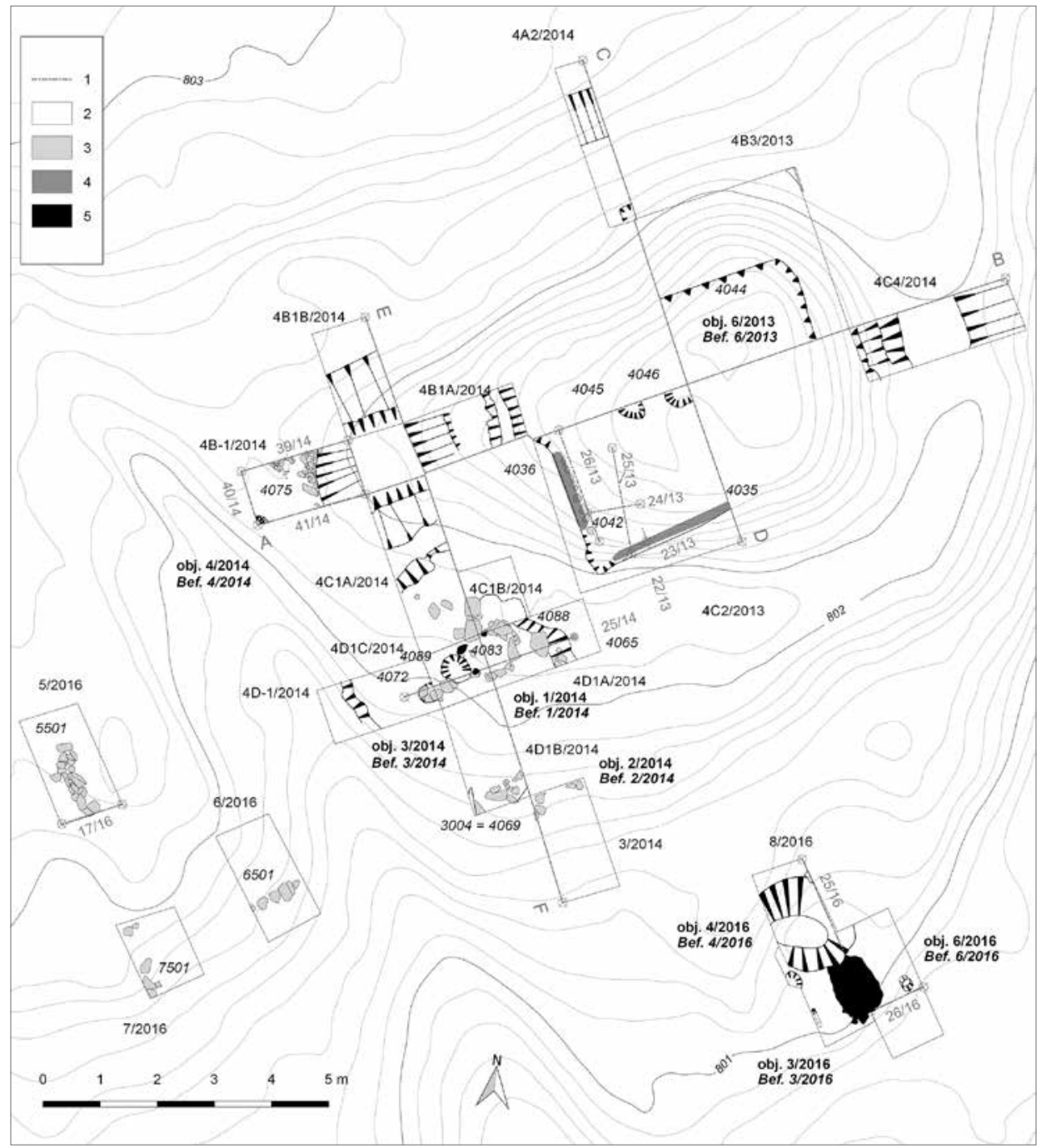

Obr. 22. Kremsiger. Plán sond v okolí domu III. 1 - profily; 2 - hranice sond; 3 - kameny; 4 - dřevo; 5 - propálená hlína. Podle Derner 2018.

Abb. 22. Kremsiger. Plan der Sondierschnitte in der Umgebung von Haus III. 1 - Profile; 2 - Grenze der Sondierschnitte; 3 - Steine; 4 - Holz; 5 - verbrannter Lehm. Nach Derner 2018.

Abb. 107); severoněmecké, či naopak jihoněmecké tradici pak odpovídá umístění zahloubených prostor do zadní, resp. přední části domů (k tomu včetně kritického zhodnocení tohoto dělení Küntzel 2009, 139-141). Jako extrémní možnost lze připustit, že některé drobné sklípky mohly stát samostatně bez nadzemní stavby (Lobbedey 1998, 27). V poslední době přichází do obliby představa malého podsklepeného nadzemního domu spočívajícího na samostatných základech lemujících vnější okraj stavební jámy sklepa (obr. 32 a 33). Její výhodou je, že obchází již nepopulární koncept zemnice, ale zároveň nevyžaduje doklad nadzemních konstrukcí, o nichž se předpokládá, že se vlivem eroze sesunuly do nitra sklepa. Odpovídá také zjištěným skromným výměrám nadzemních hornických obydlí. 


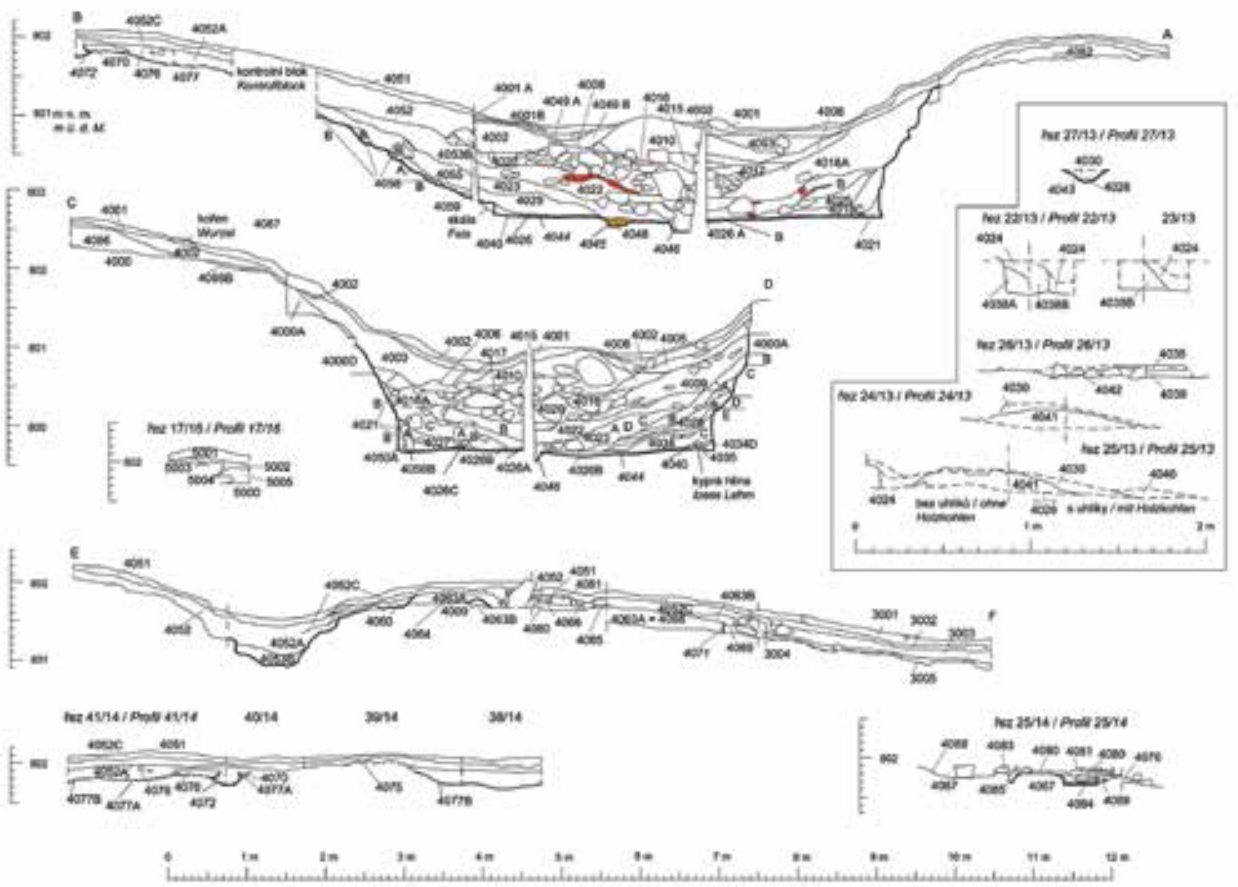

Obr. 23. Kremsiger. Řezy domem III. Šedě - propálená hlína. Podle Derner 2018.

Abb. 23. Kremsiger. Schnitte durch Haus III. Grau - verbrannter Lehm. Nach Derner 2018.

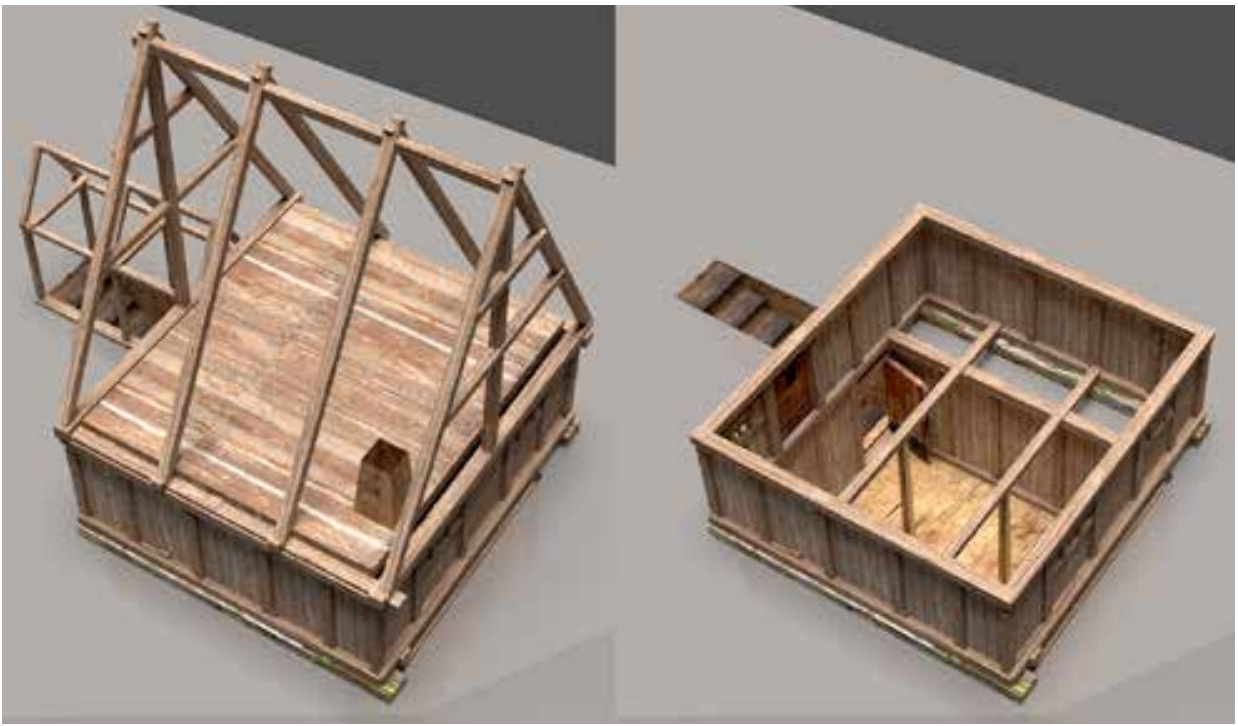

Obr. 24. Kremsiger. Rekonstrukce domu jako malé podsklepené nadzemní stavby se záklopovým stropem a dýmníkem. Podle Derner 2018.

Abb. 24. Kremsiger. Rekonstruktion eines Hauses als kleiner unterkellerter oberirdischer Bau mit Balkendecke und Rauchabzug. Nach Derner 2018. 


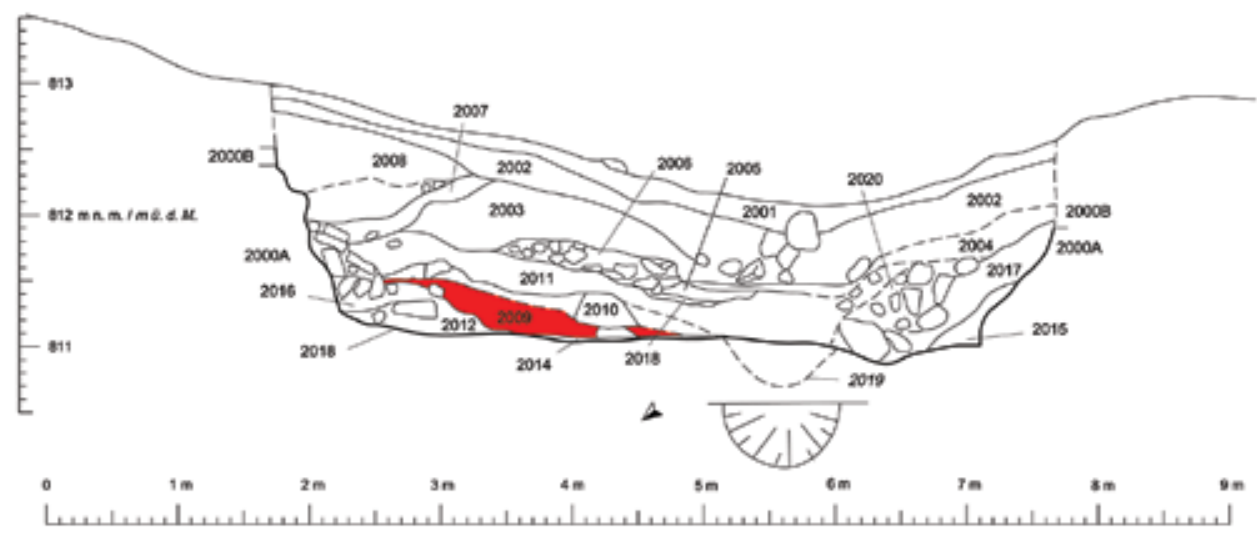

Obr. 25. Kremsiger. Řez domem XLV. Šedě - propálená vrstva. Podle Derner 2018.

Abb. 25. Kremsiger. Schnitt durch Haus XLV. Grau - Brandschicht. Nach Derner 2018.

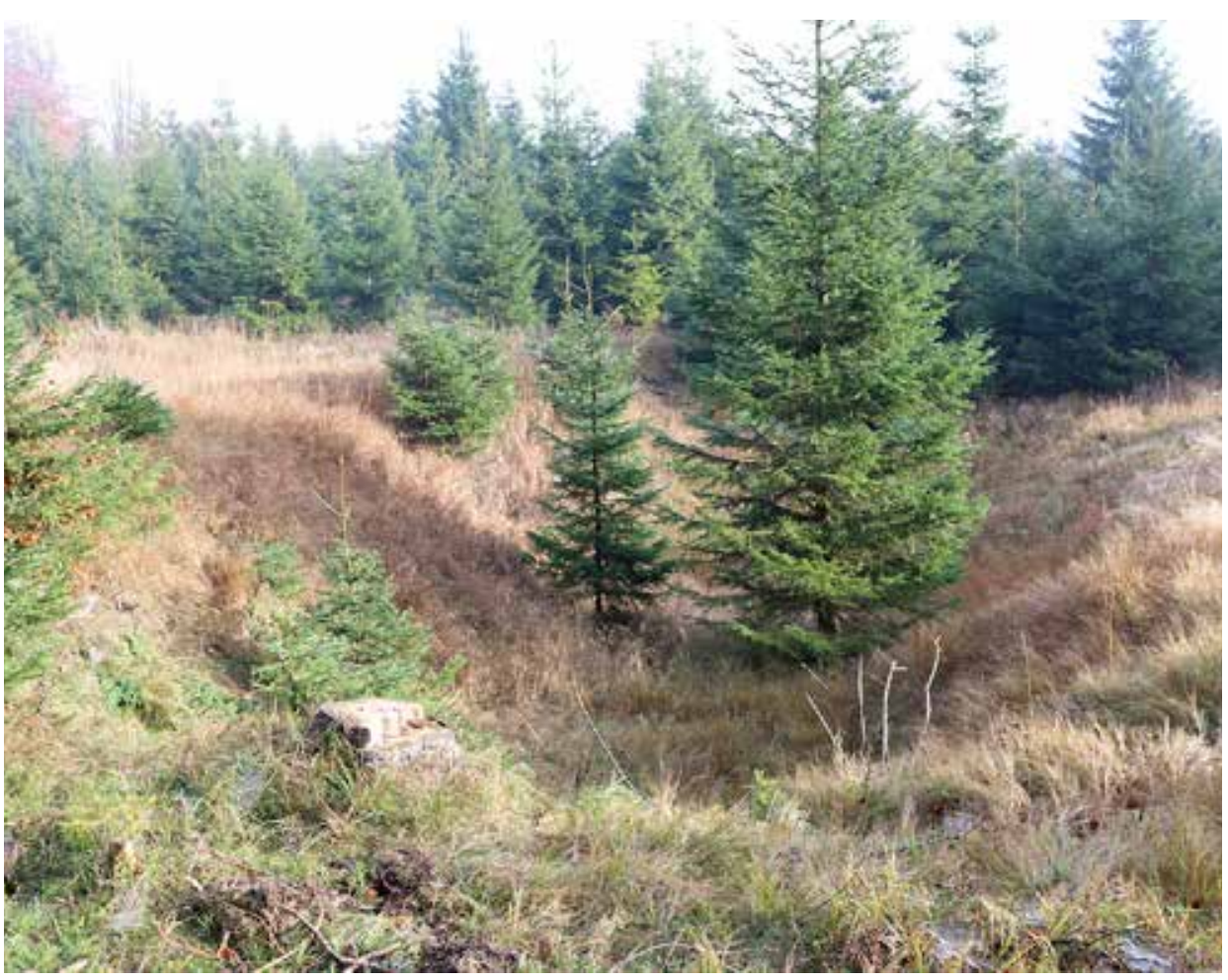

Obr. 26. Kremsiger. Dủm X před exkavací. Foto K. Derner, 2017.

Abb. 26. Kremsiger. Haus X vor der Aushebung. Foto K. Derner, 2017. 


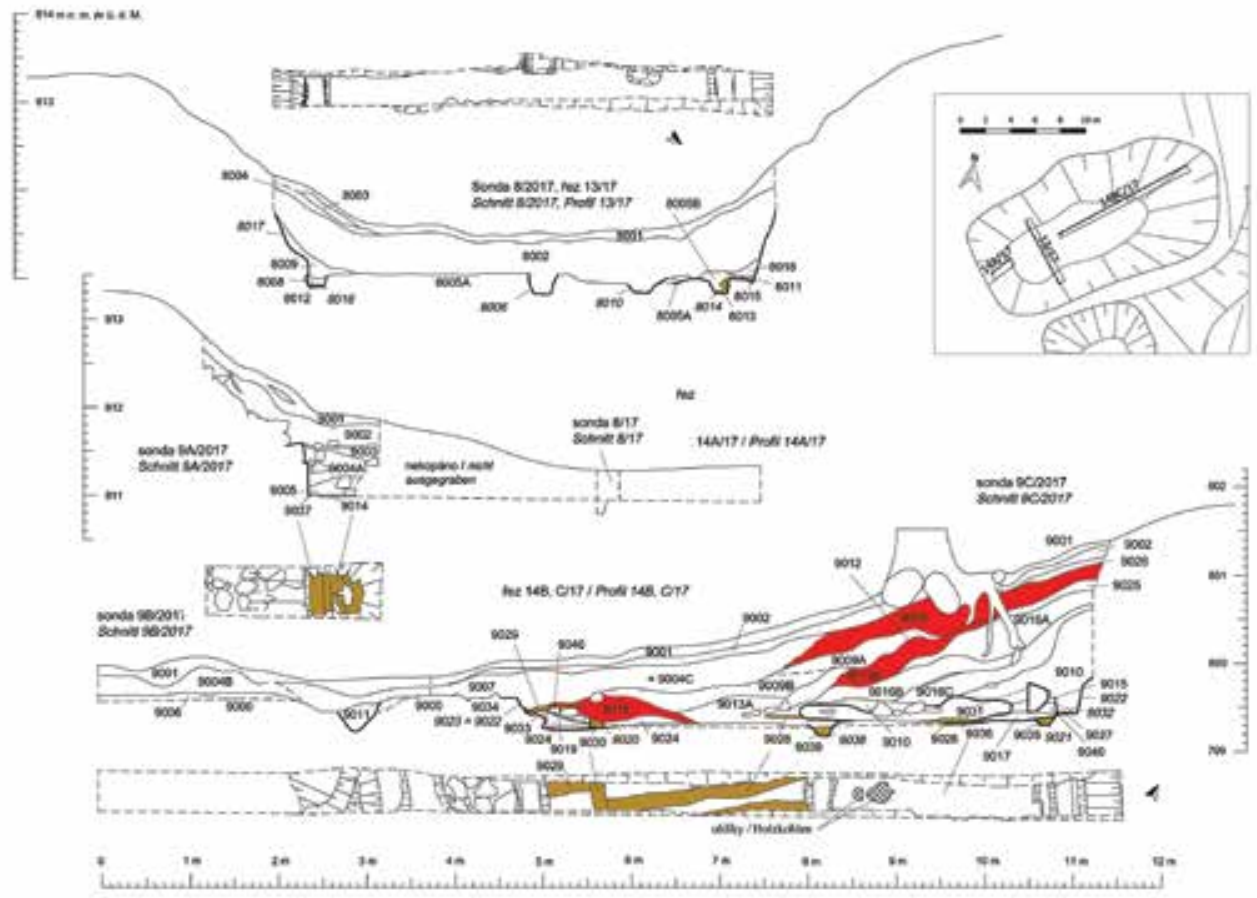

Obr. 27. Kremsiger. Půdorys a řezy domem X. Šedě - v půdorysu dřeva, na profilu propálená hlína a mazanice. Podle Derner 2018.

Abb. 27. Kremsiger. Grundriss und Schnitte durch Haus X. Grau - im Grundriss Holz, auf dem Profil verbrannter Lehm und Hüttenlehm. Nach Derner 2018.

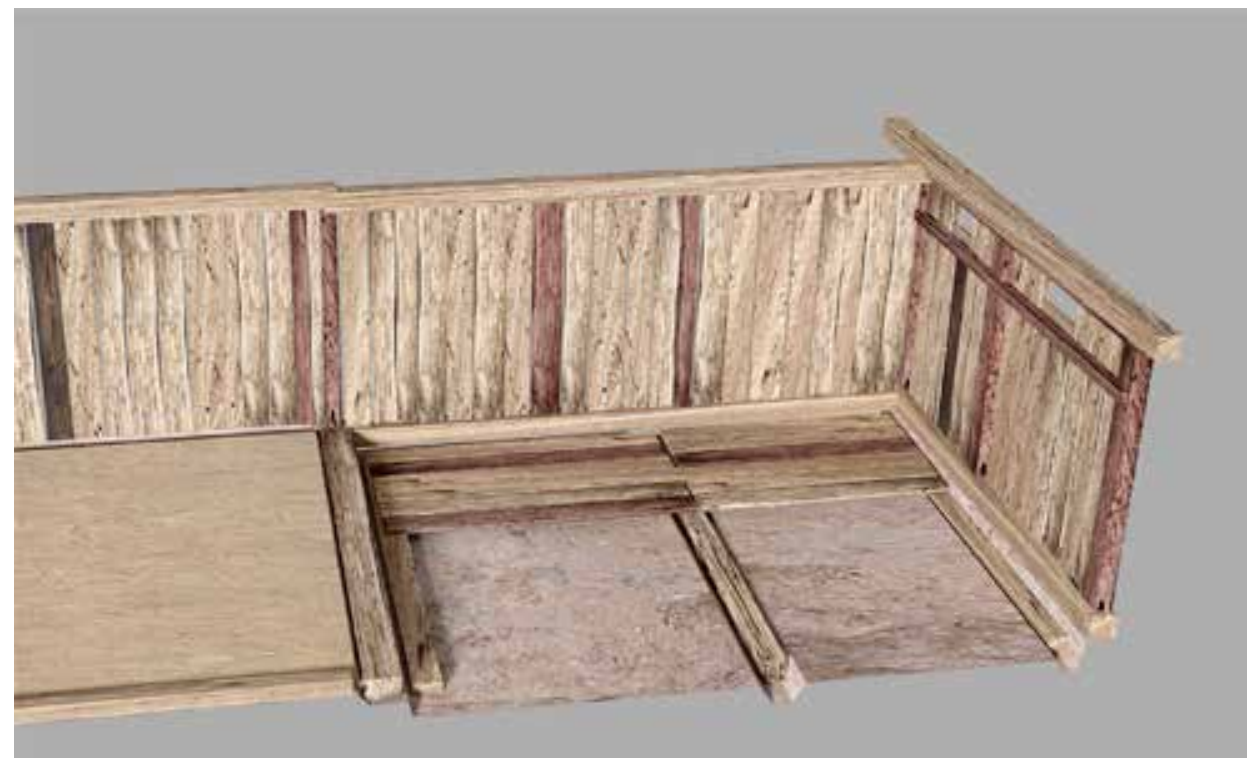

Obr. 28. Kremsiger. Rekonstrukce podlahy východní části domu X. Podle Derner 2018.

Abb. 28. Kremsiger. Rekonstruktion des Fußbodens im östlichen Teil von Haus X. Nach Derner 2018. 


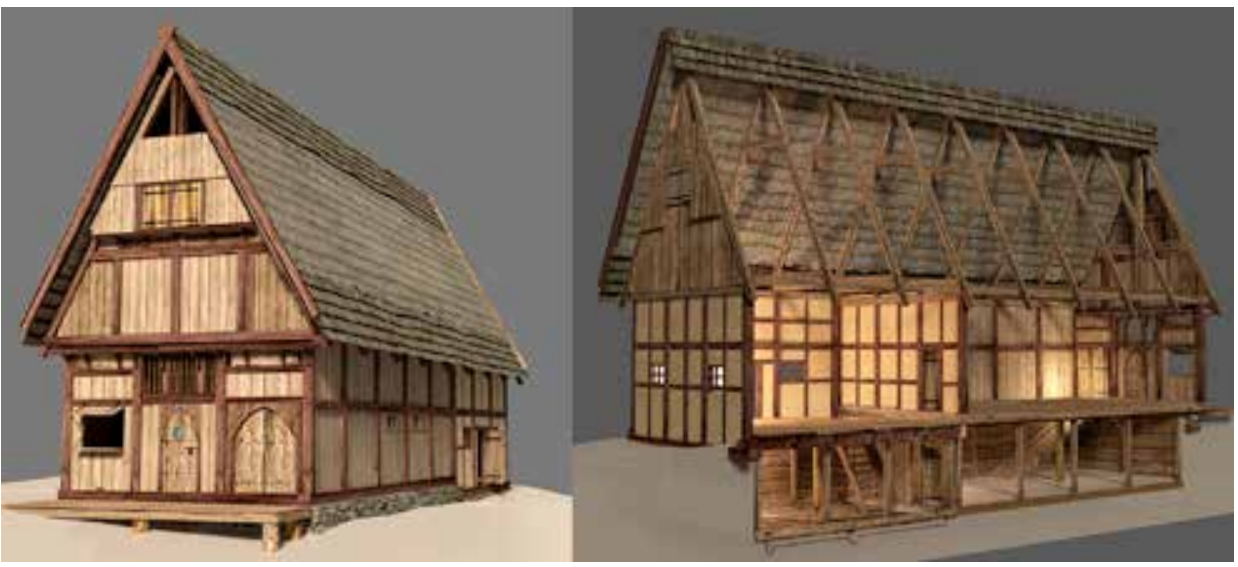

Obr. 29. Rekonstrukce stavby $X$ na Kremsigeru jako kompletně podsklepeného nadzemního domu. Abb. 29. Rekonstruktion des Baus $X$ auf dem Kremsiger als komplett unterkellertes oberirdisches Haus.

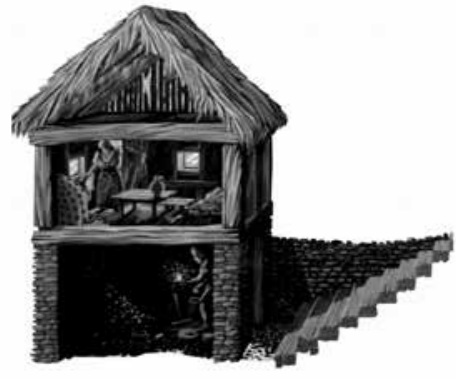

1

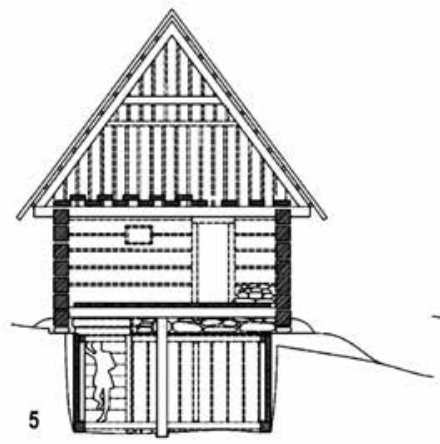

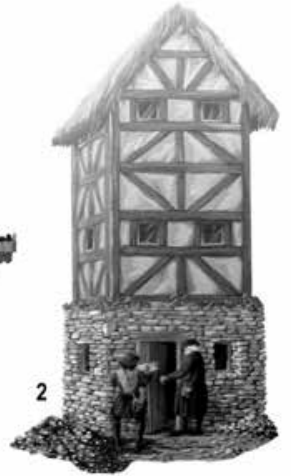

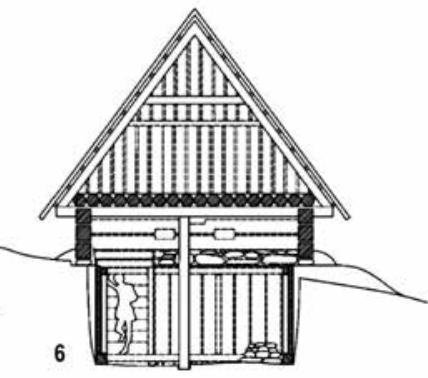

4

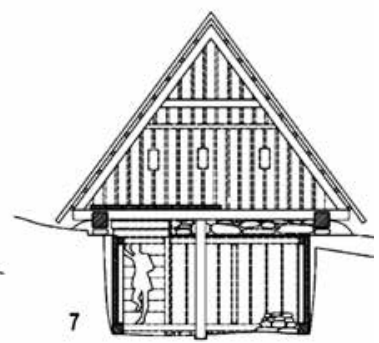

Obr. 30. Ukázky rekonstrukěních představ středověkých dřevohliněných anebo kamenných domů, zpravidla v prostředí hornických provozů a osad. 1 a 2 - Altenberg u Müsenu, expozice DBM Bochum; 3 - Sachsenburg-Treppenhauer. Podle Schwabenicky 2009, 228, Abb. 423; 4 - Brandes en Oisans. Podle Bailly-Mâitre 2002; 5-7 - představy tř́i hlavních variant stř̌edověkých dřevohliněných staveb, po nichž nacházíme charakteristické zahloubené části. Podle Derner 2015.

Abb. 30. Beispiele rekonstruierter Vorstellungen von mittelalterlichen Holz-Lehm-Bauten oder Steinhäusern, in der Regel in der Umgebung von Bergbaubetrieben und -siedlungen. 1 und 2 - Altenberg bei Müsen, Ausstellung DBM Bochum; 3 Sachsenburg-Treppenhauer. Nach Schwabenicky 2009, 228, Abb. 423; 4 - Brandes en Oisans. Nach Bailly-Mâitre 2002; 5-7 - Vorstellungen von den drei Hauptvarianten mittelalterlicher Holz-Lehm-Bauten, von denen wir die charakteristisch eingetieften Teile vorfinden. Nach Derner 2015. 


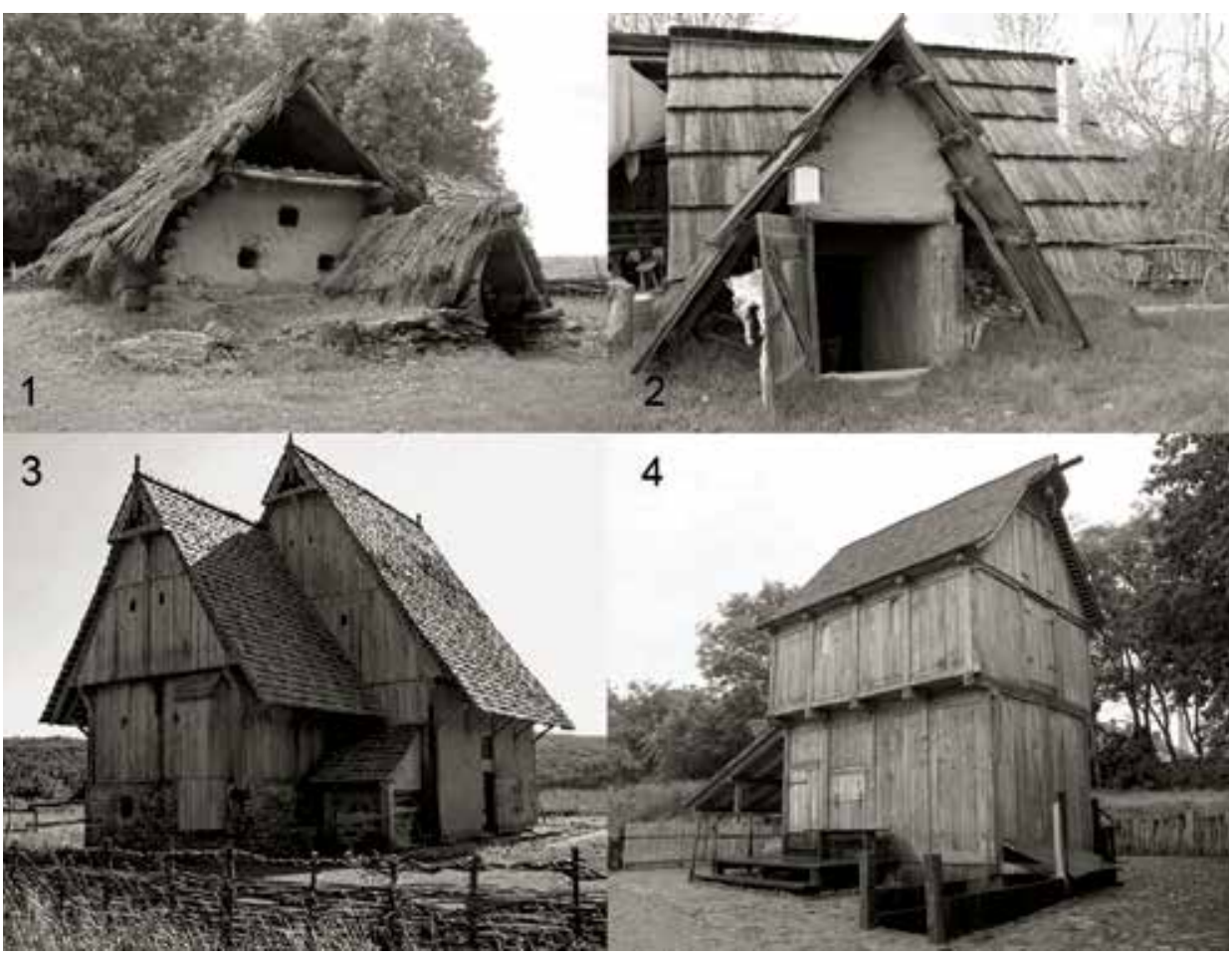

Obr. 31. Různé př́ístupy k fyzické rekonstrukci domů se zahloubenou částí převážně ve městech. 1 - Villa Nova Uhřínov. Zdroj https://www.villanova.cz/zakladni/nggallery/page/2/image/kif_0743-4); 2 - Freilichtmuseum Treppenhauer. Foto K. Derner; 3 - Mittelalterhaus Nienover. Zdroj https://www.google.com/search?q=mittelalterhaus+nienover; 4 - Geschichterlebnisraum Roter Hahn (Lübeck). Zdroj https://www.geschichtserlebnisraum.de/kaufmannshaus.html.

Abb. 31. Verschiedene Ansätze zur physischen Rekonstruktion von Häusern mit eingetieftem Teil überwiegend in Städten. 1 - Villa Nova Uhř́nov. Quelle https://www.villanova.cz/zakladni/nggallery/page/2/image/kif_0743-4); 2 - Freilichtmuseum Treppenhauer. Foto K. Derner; 3 - Mittelalterhaus Nienover. Quelle https:/www.google.com/search?q=mittelalterhaus+nienover; 4 - Geschichtserlebnisraum Roter Hahn (Lübeck). Quelle https://www.geschichtserlebnisraum.de/kaufmannshaus.html.

Jaké jsou však opory těchto rekonstrukcí v hornickém prostředí? Tristní stav bádání je zřejmý ze stručného přehledu archeologicky zkoumaných staveb. V současnosti disponujeme čtyřmi doklady vnější nadzemní konstrukce. Na jihlavských Starých Horách jsou to sloupové jamky v blízkosti suterénů 5603, 5692 a 6534, které ale neposkytují bližšśi vodítko pro jejich začlenění do konkrétní části půdorysu nadzemního domu. Na lokalitě Treppenhauer se vně malé zahloubené prostory s pecí nacházely dvě velké sloupové jamky. Podle Schwabenickyho se jedná o podzemní prostor lázně, resp. sauny 6F/O9 (2009, 75-78, Abb. 174).

Začlenění sklepů do př́ípadných nadzemních domů můžeme pouze velmi opatrně odhadovat z terénní konfigurace, umístění sklepů na „parcele“ a orientace vstupních šíjí. Ty směřují $\mathrm{v}$ první řadě domů na Vyskytné směrem $\mathrm{k}$ dolům, takže bychom mohli na základě analogií z měst předpokládat, že se nacházejí v zadních částech štítově orientovaných domů, čemuž by také odpovídala velká variabilita jejich vzdálenosti $\mathrm{k}$ hypotetické uliční čáře vyměřené podél šachet. Na sídlišti Kremsiger vidíme náznak šachovnicového uspořádání sklepů (stř́íání zadní a přední části domu), kde sklepy v prrední části jsou charakteristicky více „Zarovnané“ podle okraje veřejného prostranství.

Svědectví zásypů staveb je rozporuplné. Faktem je, že suterény zaniklé požárem vykazují ve výplni takřka pravidelně i mazanici z nadzemních konstrukcí. Překvapivě však málokdy 
hned v nejnižší vrstvě, což je ale rozšsiřený jev i v situacích, kdy evidentně shořel podsklepený nadzemní dům (Kaiser a kol. 2005). Shořelé konstrukce se nejspíš hroutily až po určité době, kdy do interiéru již pronikly splachy či erodovaly zemní stěny. Až na výjimky proto nelze posoudit, nakolik je oprávněná dříve rozšířená interpretace těchto vrstev jako sekundárního uložení požárových destrukcí vně zemnic stojících staveb či pecí a nakolik se jedná o vlastní nadzemní konstrukce. Stejně obtížné je bez analýzy dochovaných mazanic posoudit, zda shořel strop s výmazem, stěny (roubené, hrázděné) či štít. Určitým vodítkem by mohla být mocnost těchto vrstev, jejich horizontální rozprostření v zásypu a jejich uspořádanost, resp. promísenost. Za výraznější destrukci (př́zemí, izolovaný strop) bývá považováno ca $40-60 \mathrm{~cm}$ požárové vrstvy (Kaiser a kol. 2005, 105; Velímský 1991, 15).

Nejvíce konstrukčních detailů poskytly mazanice z jihlavských Starých Hor. Výjimečným dokladem stropu, jehož kostru tvořily kuláče, je požárová destrukce s ohořelými dřevy ve výplni stavby, která byla zkoumána v severní části někdejší hornické aglomerace v roce 2014 (viz výše). O zastropení uvažujeme též u domu X na lokalitě Kremsiger. Zastropení může být považováno za izolaci vytápěného i chladného prostoru, takže o obytnosti nerozhoduje.

Náznakem nadzemních konstrukcí mohou být také zlomky malty a kachlů v zásypu sklepů na hornickém sídlišti Altenberg v Siegerlandu. Z dokumentace si však nelze udělat jasnou představu o množství těchto nálezů.

\section{Antropologická a ekonomická rovina: Proč by se mělo nebo nemělo hornické prostředí lišit od městského a vesnického?}

Některé domněnky o příčinách odlišných podmínek pro hornickou zástavbu lze snadno vyvrátit. Např́iklad že sklon ke stavbě zemnic je dán drsným klimatem či snahou uspořit dřevo potřebné pro výdřevu dolů. Domnělé zemnice se stavěly i v relativně nízko položených hornických sídlištích, a naopak i u vysoko položených měst $\mathrm{k}$ trvalému uplatnění zemnic nedošlo. Nedostatek stavebního dřeva v době zakládání hornických sídlišt' musel být logicky menší než později $\mathrm{v}$ době rozvinuté těžby, kdy by měla být zahloubená provizoria nahrazována na dřevo náročnějšími nadzemními domy. Mnohem hůře na tom musela být města v přirozeně bezlesých oblastech.

Naopak za zvážení stojí předpoklad, že horníci žili při nejistotě výtěžku ve stavu jakéhosi „trvalého provizoria“. Ten by se mohl odrážet v dlouhodobém přetrvávání provizorních typů obydlí a celkově méně plánovitém urbanistickém řešení než ve městech.

Druhým závažným argumentem pro zvláštnosti hornické architektury je odlišná ekonomika hornických sídlišt', která v zásadě kromě rudy nic neprodukují, ani ve velkém neobchodují, a nepotřebují tedy odpovídající výrobní ani individuální skladovací prostory.

\section{Provizorní charakter obydlí a sídlišt'}

Je otázkou, nakolik si provizornost hornických sídlišt' jejich středověcí obyvatelé uvědomovali. Nepochybně je třeba rozlišovat perspektivu celého sídliště a jednotlivých horníků i jejich usedlostí. Doba existence popisovaných hornických sídlišst' se pohybovala většinou mezi 50 až 100 lety (obr. 34). U některých se během této doby vyvíjí více sídelních jader, jako ve středisku Buchberg či v Jihlavě na Starých Horách, jejichž vznik by bylo možné vysvětlit např́íklad postupem dolování podél rudné struktury, nebo jako zakládání sídlišst' různých těžařstev apod. Na většině sídlišt' však k zásadním změnám rozvržení nedochází, dokud se případně neproměnila ve skutečné město typu Kutné Hory či Freibergu, což bylo spojeno s vymezením areálu města a jeho důsledným novým rozparcelováním. Spíše než vysloveně provizorní byla zástavba od počátku jednodušeji organizovaná, vyvíjející se extenzivně bez přesně vymezených hranic. Možná by se dalo jako projev provizornosti hodnotit úplné chybění kamenné nadzemní architektury. To ale platilo i pro nejedno soudobé poddanské město. 

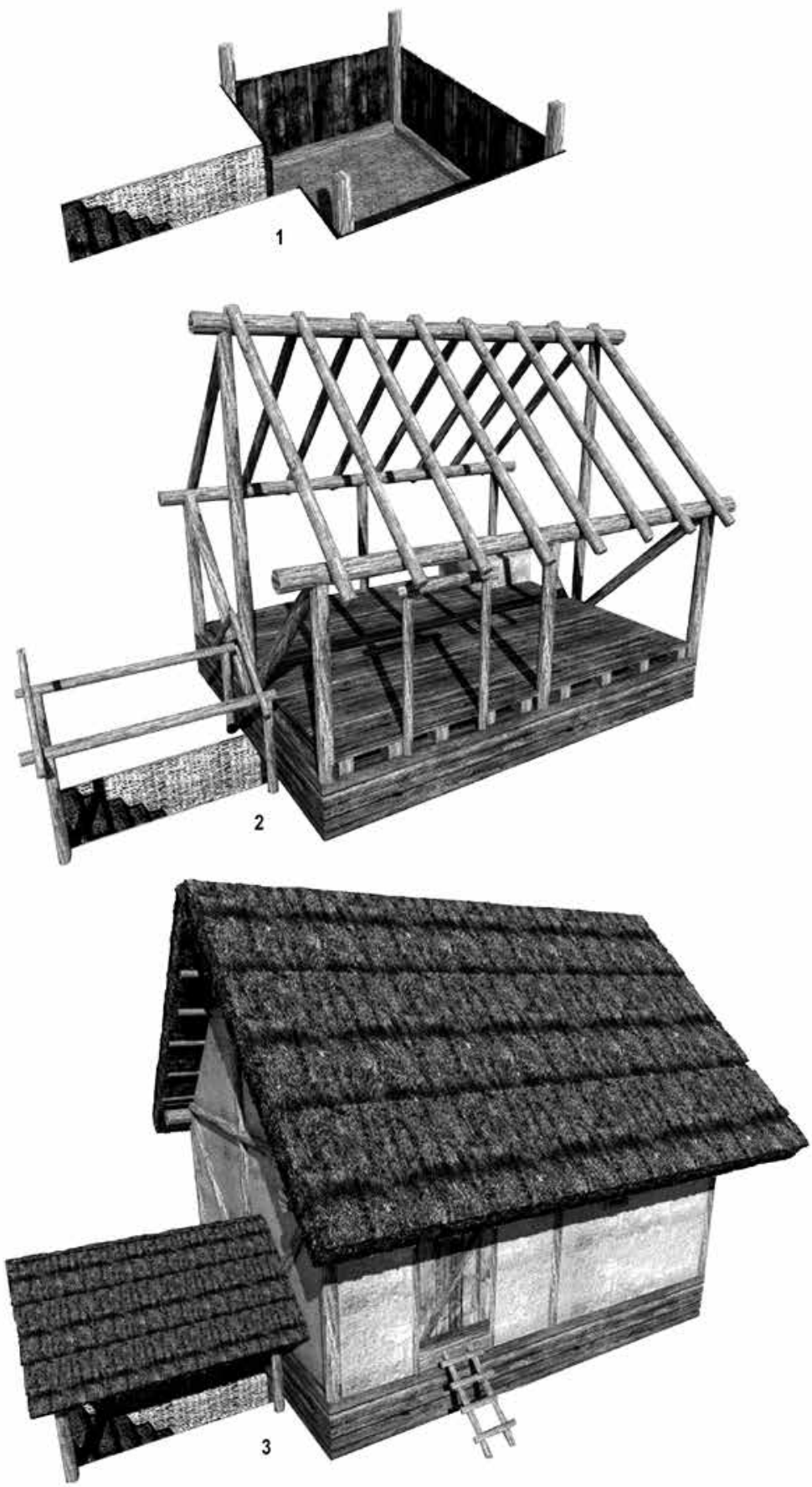

Obr. 32. Ideální trojrozměrný model středověkého domu z hornického sídliště s dřevěným suterénem. Podle podkladů vytvořil M. Vágner, úprava P. Hrubý.

Abb. 32. Ideales dreidimensionales Modell eines mittelalterlichen Hauses mit Souterrain aus Holz aus einer Bergbausiedlung. Nach Vorlagen erstellt von M. Vágner, bearbeitet von P. Hrubý. 


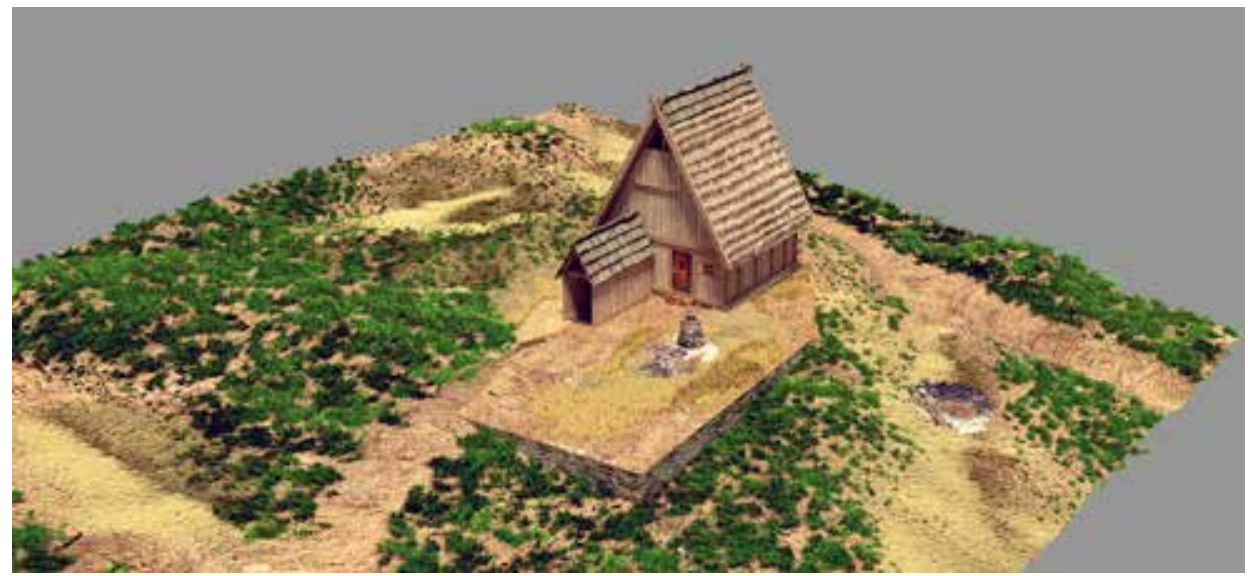

Obr. 33. Ideální trojrozměrný model domu III z Kremsigeru s doprovodnými pyrotechnologickými zařízeními a sítí cest. Podle Derner 2018.

Abb. 33. Ideales dreidimensionales Modell von Haus III vom Kremsiger mit begleitenden pyrotechnologischen Anlagen und Wegenetz. Nach Derner 2018.

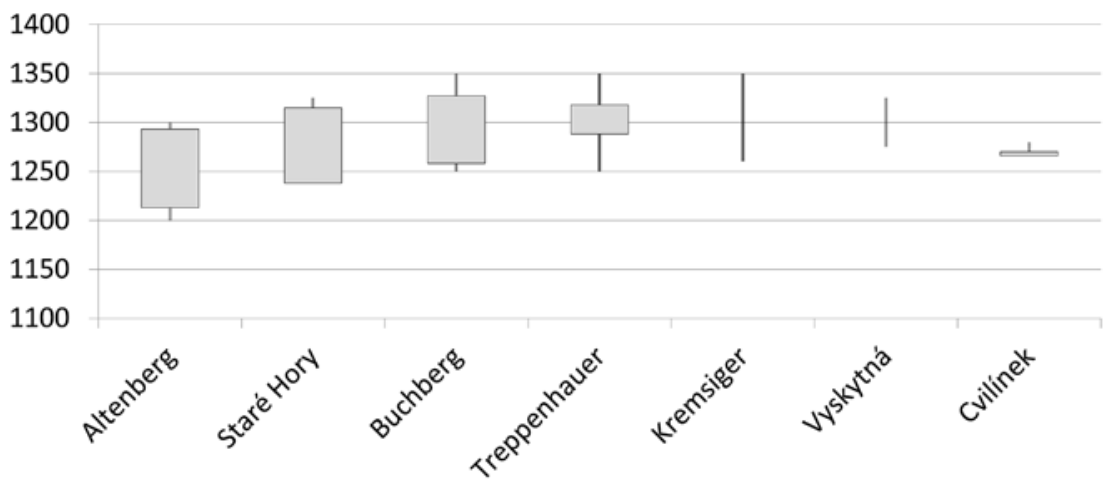

Obr. 34. Datace vybraných hornických sídlišt’ a její zdroje. Obdélník-dendrochronologie, písemné prameny nebo mincovní nálezy datují počátek i konec období; čára - datace podle chronologie keramiky. Autor K. Derner podle Hrubý 2011; Hrubý a kol. 2012; 2016; Lobbedey 1998; Schwabenicky 2009.

Abb. 34. Datierung ausgewählter Bergbausiedlungen und ihre Quellen. Rechteck - Dendrochronologie, schriftliche Quellen oder Münzfunde datieren Anfang und Ende des Zeitraums; Linie - Datierung nach Chronologie der Keramik. Erstellt von K. Derner nach Hrubý 2011; Hrubý a kol. 2012; 2016; Lobbedey 1998; Schwabenicky 2009.

Nejisté vyhlídky setrvání na místě museli mít jednotliví horníci, a tím i jejich obydlí. Ta nebyla svázána s půdou jako na vesnici ani se zpoplatněnou parcelou jako ve městě, aby je bylo třeba vždy obsazovat, takže lze předpokládat jejich častější pustnutí. Př́ímé doklady existují jen u trvalejších sídlišt' jako Brandes, kde byly opuštěné domy přesypávány odpadem žijících usedlostí (Bailly-Maître 2016, 60). Důsledkem stále nových staveb domů i v těsné blízkosti předchozích může být obrovské množství domů na magnetogramech Vyskytné či domy v horizontální superpozici na lokalitě Cvilinek. Oproti městům lze připustit také větší dynamiku vývoje jednotlivých parcel zapříčiněnou pokračující těžbou, jak dokládají hlušinou zasypané domy v německém středisku Altenberg a na jihlavských Starých Horách.

Avšak ani existenčními nejistotami nelze podpořit Schwabenickyho představu horníků žijících řadu let v provizorních zemnicích, než se vzmohli na stavbu nadzemního domu (2009, 
226). Je těžké si představit, že tento vývoj byl dokončen v jednotlivých případech jen v okrajových částech na lokalitě Treppenhauer, zatímco hlavní dvě řady zemnic podél cesty zůstaly nepřestavěny (tak i Kenzler 2008, 291).

Není také zcela jasné, zda skutečná provizoria bývala zahloubená, nebo nadzemní. Srovnávacím souborem mohou být obléhací tábory. Zdá se, že tábory stavěné $\mathrm{v}$ zimě byly skutečně častěji zahloubené, i když to není pravidlem (Kypta-Podliska 2014). Doba provizorního bydlení však pochopitelně nepřekračovala několik měsíců. Jiným referenčním souborem mohou být dřevařské osady. Šumavská obydlí z 19. století líčí například K. Klostermann v povídce „Zmizelá osada“ (2008). Životní podmínky rodin byly podobné, jaké se předpokládají u zemnic: nedostatek světla při napevno zavřených okenicích, vytápění jednoduchým ohništěm uprostřed místnosti, dým unikající otvorem ve stropu do podkroví. I zde však provizorium trvalo nejvýše pět až deset let. Na rozdíl od hornických sídlišt's doklady elitního importovaného zboží se jednalo spíše o obydlí chudších vrstev.

\section{Potřeba skladovacích prostor}

V souvislosti se zasypanými zahloubenými stavbami na lokalitě Treppenhauer překrytými nadzemními domy vyslovil W. Schwabenicky domněnku, že je to důkaz jejich obytného charakteru, protože kdyby to byly sklepy, došlo by k zániku skladovací prostory bez náhrady (2009, 230). Na to lze jistě namítnout, že neznáme historii jednotlivých parcel, např́́klad zda stavitel nadzemního domu nevlastnil současně i jiný obytný dům se sklepem apod. Problém lze však nazírat i z jiné stránky. K čemu by horníci vůbec potřebovali takto rozměrné sklepy?

Jako uzamykatelné místnosti byly vhodné k uskladnění cenností a skladovat se zde nakonec mohla ojediněle i vytříděná ruda, jejíž drobné zlomky byly nalezeny v podlahových vrstvách zahloubených staveb ve středisku Altenberg - charakteristicky na parcele s prubířskou pecí (Dahm-Lobbedey-Weisgerber 1998, 97) a na sídlišti Geißmättle u Sulzburgu ve sklepě usedlosti 3. fáze sídliště, kdy autoři výzkumu doprovodné nášlapy uhlíků interpretují jako pozůstatky skladu dřevěného uhlí (Spiong 1999, 79). Vzhledem k tomu, jak cennou ruda byla, nelze očekávat její nálezy v zaznamenáníhodné velikosti. Při výzkumu může snadno pozornosti uniknout. Přesto se nedomníváme, že by se jednalo o rozš́iřený jev, protože vytěžená ruda nebyla patrně na větších dolech v individuálním vlastnictví. Rovněž její objem nevyžadoval tak rozměrné sklepy, nehledě na možnosti skladovat ji nad zemí.

Podzemní skladovací prostory nabízejí chladné a vlhké prostředí vhodné k uchovávání tekutin, rostlinných plodů, snad i nakládaných potravin jako slanečci či zelí. Doloženo je i skladování obilí v sudech. Provozovaly se v nich také výrobní činnosti jako produkce textilu, mléka a piva, které však na hornických sídlištích ve větším měřítku nepředpokládáme (k využití sklepů Küntzel 2009, 196-198). V písemných pramenech je naopak zdůrazňován spotřební charakter těchto lokalit. Zásobování hornických sídlišt' přinášelo totiž nemalý zisk městům v jejich zázemí, resp. jejich vrchnostem (Hrubý-Derner 2018). Velký sklep na sídlišti Kremsiger je zřejmě ojedinělým dokladem skladů tohoto zboží na hornických sídlištích. Pokud by ostatní zahloubené prostory měly sloužit pouze skladování individuálních zásob, působily by skutečně jako zbytečně velké. Horníci by měli mít srovnatelné potřeby na skladování v chladných studených prostorách jako obyvatelé vesnic či řemeslných předměstí, kde vaření piva ani větší sklady zboží nepředpokládáme.

Přehled výskytu a podoby sklepů v tomto prostředí poskytuje pestrý až nepřehledný obraz. Každopádně zde nepatřily dlouho k obligátní části domu a i jejich velikosti značně kolísají. Sklepy v českých a moravských zaniklých středověkých vesnicích jsou spíše výjimečné, malých rozměrů (Mstěnice, Vilémov, Konůvky, největší na Pfaffenschlagu $-3,8 \times 2,2 \mathrm{~m}$ ). Někde se jedná spíše jen o lochy. Jejich funkci v některých oblastech přebírala zčásti zahloubená komora, spojená se špýcharem v patře. V řadě vsí (Bystřec, Hol, Svídna) se sklepy nacházejí pouze ve spojení s největší usedlostí na vsi, interpretovanou jako rychta s krčmou nebo sídlo drobného feudála. Tyto bývají někdy i velmi prostorné, srovnatelné s domem X na sídlišti Kremsgier, 
například sklep z 15. století ve vsi Rovný (Novák-Vařeka 2016, 217). Zcela obdobná je situace v Německu, kde sklepů, a to zděných přibývá na vesnicích až v pozdním středověku, poté co jsou již cela běžné ve městech (Donat 2003, 224-227). Sklepy se stávají běžnější až v 18. století s rozšířením pěstování brambor a řepy. Stručný výhled do novověku ukazuje, že na hornických sídlištích se již sklepy nevyskytují a v (krušnohorských) horních městech byly velmi malé, většinou s integrovanou studánkou. Z řemeslnických předměstí jmenujme situaci v Sezimově Ústí, kde se polozahloubené zděné prostory objevují ve třech domech (Richter-Krajíc 2001). Jejich výbava nijak nenapovídá, proč je bylo třeba do nadzemních domů integrovat.

$\mathrm{Z}$ tohoto rychlého přehledu je snad možné formulovat závěr, že individuální sklípky pro skladování potravin nebyly mimo městské prostředí nezbytné. Je ovšem třeba si uvědomit, že chladné skladovací prostory mohly $\mathrm{v}$ nadzemních domech zajistit zděné komory a případně zásobní jámy na parcelách. O tyto možnosti by byly hornické domy jako zemnice ochuzeny. V jejich zázemí totiž nebyly dosud ani přes rozsáhlé plošné výzkumy nalezeny žádné podzemní zásobní prostory, ani zlomky keramických zásobnic (Derner-Hrubý 2018).

Co když ale není výskyt sklepů na hornických sídlištích fenoménem ekonomickým, ale kulturním? Jestliže v německých městech proběhla evoluce sklepů již ve 12. století (Donat 2003), mohly být v hornických sídlištích 13. století přijaty podsklepené domy již jako normovaný a ověřený kolonizační stavební typ pro vstup na nejistou půdu nových založení, a to bez ohledu na reálnou potřebu skladovacích prostor. Snad i proto vypadá první generace sklepů napříč různými typy sídlišt' uniformně. $\mathrm{V}$ dalším vývoji pak mohly být sklepy přizpůsobeny skutečným potřebám obyvatel, v krajním případě i zasypány (Holub a kol. 2018, 830). Jejich kapacita nemusela být využívána naplno, ani zcela racionálně. Dodnes se stávají skladišti nejrůznějšího nepotřebného harampádí, nástrojů apod. Podobný obraz poskytují i rychle zaniklé sklepy středověké (Küntzel 2009, 196).

\section{Závěr}

Urbanismus a ještě více podoba staveb na hornických sídlištích a ve městech tvoří spojité nádoby. V dosavadním studiu obou sídelních forem byly bohatě využívány koncepty a poznatky vzniklé v táboře montánní i městské archeologie. Oprávněným předpokladem totiž je, že architektura hornických sídlišt' 13. století se inspirovala v architektuře měst vyzrálé na západ od našich hranic v předchozím století. Otázkou však je, jaké mají tyto analogie meze. Jde o to, zda se $\mathrm{v}$ hornických centrech nevyvinula vlivem jiných společenských a ekonomických podmínek odlišná stavební kultura, která městské formy jen připomíná. Výraznější odlišnosti konstatujeme jen u urbanismu, který je mnohem volnější. Oproti tomu stavby jsou podobné těm městským. Tak pro interpretaci zahloubených staveb jako obytných zemnic neexistuje o nic víc dokladů než pro městské prostředí, naopak řada indicií hovoří pro existenci podsklepených domů i v hornických centrech. Shodu mezi městskými a hornickými zahloubenými stavbami nelze vysvětlit ustrnutím ve stadiu provizoria, zejména proto, že doba existence hornických sídlišt' se ve skutečnosti vymykala všem měřítkům provizornosti. Účel relativně velkých sklepů na hornických sídlištích ale také není jasný. Přikláníme se k názoru, že byly přejaty jako součást typového kolonizačního domu bez ohledu na skutečnou potřebu chladných vlhkých prostor.

Tyto závěry jsou pochopitelně předběžné a otevřené. Stav výzkumu hornických sídlišt' přes obrovské pokroky v posledních letech stále není uspokojivý. Překážkou je slabá základna písemných pramenů neumožňující postihnout všechny ekonomické aktivity obyvatel hornických sídlišt', jež by se ve stavební podobě domů mohly odrazit. Nedá se také říci, že by se daly jednoduše srovnávat poznatky z velkoplošných záchranných výzkumů, geomagnetických měření a badatelské výzkumy v lesním terénu. Chybí výzkum v rozsahu celé parcely, resp. usedlosti v nenarušeném terénu s využitím všech metod sídelní a montánní archeologie (fosfátová analýza, analýza distribuce keramických zlomků, metalometrie). Teprve v tomto rozsahu by byla šance najít stopy případných nadzemních konstrukcí, parcelních hranic a doplňkových staveb na parcele. Oproti tomu další badatelské odkryvy zahloubených částí staveb patrně mnoho nového 
nepřinesou. Sebekriticky přiznáváme, že výzkum v tomto směru zůstal zatím z různých důvodů napůl cesty. $O$ to více by se měl stát naléhavějším úkolem prrípadných budoucích projektů.

\section{Exkurz: Metody a př́istrojové vybavení geofyzikálního měření areálů zaniklých hornic- kých osad na Vysočině}

Pro průzkum architektury středověkých hornických osad se na základě terénních zkušeností projevila jako nejefektivnější magnetometrie. Pomocí magnetické prospekce lze v krátkém čase proměřit rozsáhlé plochy s výskytem podpovrchových archeologických struktur. Výsledný magnetogram neposkytuje jen informaci o př́tomnosti zaniklých struktur. Při jejich správné interpretaci se lze alespoň v základní rovině zabývat i jejich vzájemnými prostorovými vztahy. U větších a souvislejších proměřených ploch, což je případ referovaných hornických sídlišst', dává magnetogram možnost prostorově analyzovat sídlištní areály ze vzdálenější perspektivy jako celek a posuzovat je v kontextu dalších přítomných prvků pracovní a technické infrastruktury. Při průzkumu sídlištních areálů u obcí Vyskytná, Utín a na nekopané části hornické lokality Cvilinek byl nasazen fluxgate magnetometr Förster Ferex 4.032 DLG, který je konstruován jako gradiometr se čtyřmi sondami. Hustota měřených bodů byla $0,25 \times 0,5 \mathrm{~m}$, což plně postačuje pro detekci většiny archeologických struktur běžně očekávaných na ploše středověkých hornických osad.

Důležitou roli při detekci podpovrchových struktur hrají feromagnetické minerály, ale i organické složky ve výplních archeologických objektů. Při průzkumu montánních areálů spojených s těžbou a hutnictvím rud ovlivňuje kontrastní detekci podpovrchových struktur především složení zpracovávaných rud, kdy v rudnině z těles polymetalického zrudnění jsou prakticky vždy př́itomny i minerály $\mathrm{Fe}$. Z primárních rud to jsou obvykle pyrit, arsenopyrit, pyrhotin a př́padně i chalkopyrit. $V$ archeologických situacích, kde je ve výplních prítomna rudnina, pak z těchto rud vznikají zvětráváním sekundární minerály (hydroxidy, sírany, uhličitany a př́ípadně i fosfáty $\mathrm{Fe}$ ).

V areálech zaniklých hornických osad se na magnetogramech projevují také stavební prvky jako např́íklad kámen (pece, ohniště), který byl na místo přinesen z jiného magnetického prostředí a během provozu byl navíc vystaven silnému žáru. Zdrojem anomálních magnetických hodnot, které lze na magnetogramech sledovat vůči normálnímu magnetickému pozadí obzvlášt' kontrastně, jsou relikty pyrometalurgických zařízení a s nimi související koncentrace metalurgického odpadu. $Z$ hlediska geomagnetické detekce jde zpravidla o hutnické a především kovářské strusky (Hrubý a kol. 2007, 24, 27 a 28; 2012, 370).

U Vyskytné byly nejčastěji detekovány struktury přibližně čtverhranných půdorysů o velikosti 10 až $20 \mathrm{~m}^{2}$. Nejvýraznější je první (severní) řada těchto struktur, která je situována nejblíže k důlním pracovištím. V severních rozích takto chápaných staveb můžeme podle magnetogramu předpokládat vstupy směřující $\mathrm{k}$ důlním polím. Podpovrchové geomagnetické struktury považované za relikty zahloubených staveb se svými magnetickými vlastnostmi od okolí výrazně liší. Jejich výplně pravděpodobně obsahují vysoké množství propáleného materiálu a především zpracovávané rudniny, která obvykle kontaminuje archeologické výplně podpovrchových struktur i desítky metrů od důlních pracovišt'.

V porovnání se sídlišti z agrárního prostředí se pozůstatky zahloubených obydlí v hornických osadách geomagneticky projevují jako výrazné a kontrastní struktury, jak ukazuje magnetogram z Vyskytné. Naopak ale na př́íkladu magnetogramu z hornického sídliště Cvilinek můžeme pozorovat malou odlišnost a slabý kontrast mezi geomagnetickým projevem reliktů zahloubených obydlí a okolního prostředí (obr. 4). Příčinu nelze bez exkavace a geochemických či geofyzikálních rozborů půdních vzorků jasně určit. 


\section{Prameny}

TOMASCHEK, J. A., ed., 1897: Das alte Bergrecht von Iglau und seine bergrechtlichen Schöffensprüche. Innsbruck.

HRUBÝ, P., 2015: Přístavba sýrárny Moravia lacto, a.s., Jihlava - II. etapa - záchranný archeologický výzkum, číslo akce A 006/2014. Zpráva o provedení záchranného archeologického výzkumu. Archaia Brno, o. p. s., pracoviště Jihlava. Nepublikovaná zpráva.

KYNCL, T., 2014: Dendrochronologické datování dřevěných konstrukčních prvků vyzvednutých při archeologickém výzkumu v Jihlavě (výzkum A006/2014). Nepublikovaná výzkumná zpráva č. 037-14. Brno.

\section{Literatura}

ALPER, G.-RÖMER-STREHL, C., 2003: Johanneser Kurhaus: ein mittelalterlicher Blei-/Silbergewinnungsplatz bei Clausthal-Zellerfeld im Oberharz. Materialhefte zur Ur- und Frühgeschichte Niedersachsens. Reihe A, Monographien. Band 32. Rahden/Westf.

BAILLY-MAÎTRE, M.-Ch., 2002: L'argent. Du minerai au pouvoir dans la France médiévale. Paris.

- 2016: Chapitre 3. L’agglomération de Brandes. In: Bailly-Maître, M.-C.-Bruno-Dupraz, J., Brandes-en-Oisans : La mine d'argent des Dauphins (XIIe-XIVe siècles). Nové vydání [online], 105-152. Lyon.

DAHM, C.-LOBBEDEY, U., 1998: Öfen zur Metallverarbeitung. In: Dahm, C.-Lobbedey, U.-Weisgerber, G., Der Altenberg: Bergwerk und Siedlung aus dem 13. Jahrhundert im Siegerland. 1: Die Funde. Denkmalpflege und Forschung in Westfalen. Band 34, 34-36. Bonn.

DAHM, C.-LOBBEDEY, U.-WEISGERBER, G., 1998: Die Grabungen 1970-1979. In: Dahm, C.-Lobbedey, U.-Weisgerber, G., Der Altenberg: Bergwerk und Siedlung aus dem 13. Jahrhundert im Siegerland. 1: Die Funde. Denkmalpflege und Forschung in Westfalen. Band 34, 37-132. Bonn.

DERNER, K., 2015: Kremsiger in the Ore Mountains: a mining settlement or a town? In: Mining Archaeology. Perspectives, conflicts, challenges. Yearbook of the Institute Europa Subterranea 2015 (Silvertant, J., ed.), 106-130. Eichach - Gulpen.

- 2018: Hornické sídliště na Kremsigeru. In: Derner K., Středověké Hornictví a hutnictví na Př́sečnicku ve středním Krušnohoří - Veröffentlichungen des Landesamtes für Archäologie Sachsen. Band 68. ArchaeoMontan 5, 217-379. Dresden.

DERNER, K.-HRUBÝ, P., 2018: Otázka zemědělství a potravinářské produkce zemědělských hornických komunit - Farming and food production in medieval mining communities, AH 43, 207-239.

DOLEŽEL, J.-SADÍLEK, J., 2004: Středověký důlní komplex v trati Havírna u Štěpánova nad Svratkou. Př́íspěvek k dějinám těžby stříbra v oblasti severozápadní Moravy ve 13. a 14. století. Výsledky průzkumu v letech 1990-2001, edice písemných pramenů - Mittelalterlicher Bergbaukomplex im Flurstück Havírna bei Štěpánov nad Svratkou. Ein Beitrag zur Geschichte des Silberbergbaus in Nordwestmähren im 13.-14. Jahrhundert. In: Mediaevalia archaeologia 6. Těžba a zpracování drahých kovů: sídelní a technologické aspekty (Nováček, K., ed.), 43-119. Praha.

DONAT, P., 2003: Zehn Keller in Gebesee, Lkr. Erfurt. Studien zu hochmittelalterlichen Kelleranlagen, Alt-Thüringen 27, 207-264.

GECHTER, M., 2003: Das Bleiwerk Silberkaule, Gemeinde Engelskirchen, Rheinisch-Bergischer Kreis. In: Man and Mining - Mensch und Bergbau. Der Anschnitt. Beiheft 16 (Stöllner, T. et al., edd.), 155-161. Bochum.

HOLUB, P. a kol., 2003: Holub, P.-Merta, D.-Peška, M.-Zapletalová, D.-Zůbek, A., K otázce topeništ v dřevohlinitých domech ze 13 . Století v Brně, ... aneb proč neveř́íme na zemnice, Svorník 1, 75-84.

HOLUB, P. a kol., 2005: Holub, P.-Kolařík, V.-Merta, D.-Peška, M.-Zapletalová, D.-Zůbek, A., Ke stavu poznání nezděné měštanské architektury vrcholně středověkého Brna. In: Forum urbes medii aevi II. Sborník př́spěvků z konference FUMA konané 16.-18. 4. 2003, 44-101. Brno.

HRUBÝ, P., 2011: Jihlava - Staré Hory: Archeologický výzkum středověkého důlního, úpravnického a obytného areálu v letech 2002-2006. Př́íspěvek ke studiu středověkého rudného hornictví - Jihlava Staré Hory (Iglau - Altenberg): Archäologische Ausgrabungen des mittelalterlichen Bergbau-, Aufbereitungs- und Siedlungsplatzes in den Jahren 2002-2006. Zum Studium des mittelalterlichen Erzbergbaus. Dissertationes Archaeologicae Brunenses/Pragensesque 9 (Klápště, J.-Měřínský, Z., curantibus editae). Praha.

HRUBÝ, P. a kol., 2007: Hrubý, P.-Hejhal, P.-Malý, K., Montanarchäologische Forschungen in Jihlava-Staré Hory (Iglau-Altenberg, Tschechien), Zeitschrift für Archäologie des Mittelalters 35, 17-60. 
HRUBÝ, P. a kol., 2012: Hrubý, P.-Hejhal, P.-Hoch, A.-Kočár, P.-Malý, K.-Macháňová, L.-Petr, L.-Štelcl, J., Středověký úpravnický a hornický areál Cvilínek u Černova na Pelhřimovsku, PA CIII, 339-418.

HRUBÝ, P. a kol., 2014: Hrubý, P.-Hejhal, P.-Malý, K.-Kočár, P.-Petr, L., Centrální Českomoravská vrchovina na prahu vrcholného středověku: archeologie, geochemie a rozbory sedimentárních výplní niv - Central Bohemian-Moravian highlands on the threshold of the high middle ages; archaeology, geochemistry and the analyses of alluvial sediments. Opera Universitatis Masarykianae Brunensis, Facultas Philosophica. Brno.

HRUBÝ, P. a kol., 2016: Hrubý, P.-Malý, K.-Milo, P., Archeometalurgie a geofyzika středověkých areálů zaměřených na produkci drahých kovů - Archaeometallurgy and geophysics of the medieval sites specialized on precious metal production, $\mathrm{AH} 41,39-63$.

KAISER, L. a kol., 2005: Kaiser, L.-Kočár, P.-Postráněcká, K.-Široký, R., Požárem zaniklý středověký objekt ve Smetanově ulici ve Starém Plzenci. In: Forum urbes medii aevi II (Merta, D.-Peška, M., edd.), 102-117. Brno.

KENZLER, H., 2008: Struktur und Entwicklung der Bergstadt auf dem Treppenhauer. Ergebnisse der archäologischen Untersuchungen von 2005 bis 2007, Arbeits- und Forschungsberichte zur sächsischen Bodendenkmalpflege 50, 263-306.

KLÁPŠTĚ, J., 2005: Čas hledání otázek. In: Forum urbes medii aevi II (Merta, D.-Peška, M., edd.), 2-5. Brno.

KLOSTERMANN, K., 2008: Zmizelá osada. Písek.

KÜNTZEL, T., 2009: Die Stadtwüstung Nienover im Solling: Auswertung der Befunde zur Stadttopographie, Hausbau und Stadtbefestigung im 13. Jahrhundert. Rahden/Westf.

KYPTA, J.-PODLISKA, J., 2014: Tábor oblehatelů na předpolí Nového hradu u Kunratic (1420/1421) - The Hussite field camp from the siege of Nový hrad at Kunratice (1420/1421) Surface survey and a comparison with parallel sites, AR LXVI, 609-632.

LOBBEDEY, U., 1998: Zeitstellung, Struktur und Bedeutung der Bergbausiedlung Altenberg. In: Dahm, C.Lobbedey, U.-Weisgerber, G., Der Altenberg: Bergwerk und Siedlung aus dem 13. Jahrhundert im Siegerland. 1: Die Befunde. Denkmalpflege und Forschung in Westfalen. Band 34, 21-31. Bonn.

NEKUDA, V., 2007: Středověká vesnice na Moravě. Brno.

NOVÁČEK, K., 1994: Hornická sídliště - příspěvek ke studiu středověkého neagrárního osídlení. In: PA LXXXV - Supplementum 2. Mediaevalia Archaeologica Bohemica, 158-170. Praha.

NOVÁK, D.-VAŘEKA, P., 2016: A Late-Medieval manor farm in Rovný (Rokycany District, Pilsen Region), AH 41, 211-227.

RIEGER, D., 2012: Zeitliche Tendenzen und Konstruktions- kontinuitäten. Aktuelle Befunde zur Holzarchitektur der Großgrabung im Lübecker Gründungsviertel, Mitteilungen der Deutschen Gesellschaft für Archäologie des Mittelalters und der Neuzeit 24, 131-140.

RICHTER, M., 1982: Hradišt'ko u Davle. Městečko ostrovského kláštera. Monumenta archaeologica 20. Praha.

RICHTER, M.-KRAJÍC, R., 2001: Sezimovo Ústí - archeologie středověkého poddanského města. 2. Levobřežní předměstí - archeologický výzkum 1962-1988. Písek.

RICHTER, U., 1995: Archäologische Untersuchungen im Freiberg. Neue Erkenntnisse zur Frühgeschichte der Stadt. Schriftenreihe des Stadt- und Bergbaumuseums Freiberg. Freiberg.

- 2011: Der Freiberger Bergbau in der ersten Bergbauperiode: Grabungen - Funde - Denkmale. In: Aufbruch unter Tage: Stand und Aufgaben der montanarchäologischen Forschung in Sachsen. Internationale Fachtagung Dippoldiswalde 9. bis 11. September 2010. Arbeits- und Forschungsberichte zur sächsischen Bodendenkmalpflege 22 (Smolnik, R., ed.), 61-68. Dresden.

SCHENK, T., 2009: Die „Altstadt“ von Freyenstein, Lkr. Ostprignitz-Ruppin: Rekonstruktion der brandenburgischen Stadtwüstung des 13. Jhs. auf der Grundlage archäologischer Grabungen und Prospektionen und Grundzüge eines denkmalpflegerischen Konzepts. Rahden/Westf.

SCHWABENICKY, W., 2009: Der mittelalterliche Silberbergbau im Erzgebirgsvorland und im westlichen Erzgebirge: unter besonderer Berücksichtigung der Ausgrabungen in der wüsten Bergstadt Bleiberg bei Frankenberg. Chemnitz.

SPIONG, S., 1999: Die Bergleutesiedlung auf dem „Geißmättle“ in Sulzburg. In: Alter Bergbau im Sulzbachtal, Südschwarzwald. Archäologische Nachrichten aus Baden 61/62 (Steuer, H., ed.), 65-84. Freiburg.

STEPHAN, H.-G., 2009-2010: Anmerkungen und Gedanken zur fächerübergreifenden archäologischen Bergbauforschung am sächsischen Erzgebirge, Arbeits- und Forschungsberichte zur sächsischen Bodendenkmalpflege 51/52, 493-512. 
- 2010: Der Solling im Mittelalter: Archäologie - Landschaft - Geschichte im Weser- und Leinebergland; Siedlungs- und Kulturlandschaftsentwicklung; die Grafen von Dassel und Nienover. Hallesche Beiträge zur Archäologie des Mittelalters und der Neuzeit. Part 1. Dormagen.

VALENTOVÁ, J., 1999: Hornická osada Antiqua Cuthna: realita pohledem archeologického výzkumu. In: Kutnohorsko. Vlastivědný sborník 1/99, 16-19. Kutná Hora.

VAŘEKA, P., 2002: Zahloubené stavby v českých městech vrcholného středověku - zemnice nebo suterény nenalezených nadzemních domů? In: Archeologie nenalézaného (Neustupný, E., ed.), 252-285. Dobrá Voda u Pelhřimova.

VEČĚ̌A, J.-VEČEŘOVÁ, V., 2008: Středověká hornická osada ve Zlatohorském rudním revíru - „Erlitz“ nebo Altenberg? Archaeologia technica 18, 60-63.

VELÍMSKÝ, T., 1991: Město na louce: archeologický výzkum na Mariánské louce v Děčíně 1984-1989. Děčín.

WEGNER, M.-SCHUBERT, M., 2015: Die Grabung Roter Hirsch - Hochmittelalterliche Wohn- und Werkstätte der Dippoldswalder Bergleute - Archeologický výzkum Roter Hirsch - vrcholně středověké sídliště a pracovní areál horníků z Dippoldiswalde - The excavation Roter Hirsch - high medieval dwellings and workshops of the Dippoldiswalde miners. In: ArchaeoMontan 2015. Montanarchäologie im Osterzgebirge - Montánní archeologie ve východním Krušnohoří. Arbeits- und Forschungsberichte zur sächsischen Bodendenkmalpflege 30 (Smolnik, R., ed.), 207-238. Dresden.

ZEILER, M.-GARNER, J.-GOLZE, R., 2016: High Medieval Silver Mining and Non-Ferrous Metallurgy in Northern Siegerland, Germany - An Interim Report, Metalla 22, 185-201.

\section{Zusammenfassung}

\section{Die Architektur von Bergbausiedlungen an der Neige des Přemyslidenzeitalters}

Einige Strömungen der bisherigen Forschung nehmen an, dass die Architektur von Bergbausiedlungen sich durch den Einfluss der unterschiedlichen Bedingungen anders als in den Städten entwickelt hat. Ein Beispiel dafür ist die Diskussion tschechischer Forscher über hypothetische hochmittelalterliche Grubenhäuser, die angeblich nur im Umfeld des Bergbaus deutlicher vertreten gewesen sein sollen (Vařeka 2002, 274; Holub a kol. 2003, 81; kritisch dazu Klápště 2005, 3). In erster Linie muss jedoch nachgeprüft werden, ob der bisherige Fundbestand der untersuchten Bergbausiedlungen und ihrer Bauten auf etwas wie eine spezielle montane Baukultur hindeutet. Ferner muss dann geklärt werden, welche Bedingungen in Bergbausiedlungen sich von denen der städtischen Umgebung unterschieden haben.

Einzigartig ist der Städtebau von Bergbausiedlungen tatsächlich. Durch keine festen Grenzen beeinträchtigt entwickelte er sich extensiv und einzigartig, sodass es nichts derartiges wie einen Bergbausiedlungstyp gibt. Entsprechend dem Grad der Organisiertheit kann man unterscheiden zwischen Siedlungen mit einer andeutungsweise orthogonalen Anordnung Kremsiger, Anordnung nach Wegen - (mit geophysikalischen Methoden in Cvilinek auf der Böhmisch-Mährischen Höhe neu belegt, Abb. 4), mit einer Anordnung nach Gruben (Havirna, Buchberg, Siedlung bei Vyskytná, Altenberg/Erlitz (Večeřa-Večeřová 2008) und zwischen Siedlungen mit unregelmäßigen Grundrissen (Staré Hory, teilweise Cvilinek). Einige haben mehrere Siedlungskerne (Cvilinek, Buchberg). Selten kann eine regelmäßige Einteilung der Breite der „Parzellen“ belegt werden wie auf dem Kremsiger (19,5 bzw. 9 m.)

Die Häuser übernehmen die Konstruktionsgewohnheiten der umliegenden Städte. Im Raum des Römischen Reiches sind es Holz-Lehm-Häuser. Die oberirdischen Häuser gründen sich im 13. Jahrhundert zumeist bereits auf ein Holzschwellenfundament. Ihre Fläche bewegt sich meistens zwischen 12-24 $\mathrm{m}^{2}$, beheizt werden sie mit Öfen. Dadurch dass sie den Mindestbedarf der Bergleute zum Leben widerspiegeln, sind sie ein Referenzkomplex zu Wohngrubenhäusern.

Gegenüber der verbreiteten Vorstellung finden wir in Bergbausiedlungen nicht mehr Anzeichen für eine Bewohnbarkeit der Grubenhäuser als in den Städten vor. Praktisch ganz fehlt eine eindeutige Heizvorrichtung. Öfen befinden sich (sehr selten) vor allem in extrem kleinen Bauten (Saunen, bzw. Bäder), oder in solchen, die in der Verfüllung technische Keramik enthalten, 
sodass es sich um die Arbeitsstätte von Probierern gehandelt haben könnte. An einigen Siedlungen schwanken die Größen des eingetieften Raumes und umfassen auch offensichtlich keine bewohnbaren Abmessungen, was im Kontrast steht zu den oberirdischen Häusern.

Relativ selten bleiben die Indizien für in oberirdischen Häusern eingegliederte eingetiefte Bereiche. Angeschlossene Pfahlgruben wurden in Staré Hory und auf dem Treppenhauer entdeckt. Auffällig sind auch regelmäßige Nachbarschaften eines oberirdischen Hauses mit Öfen (oder nur einem Ofen) und übereinstimmend orientierten „Grubenhäuser“ auf dem Treppenhauer (Schwabenicky 2009, Objekte 6FO3, 5GO1 und 5GO2, 5DO1 und 5DO2). Konstruktionsabdrücke in Hüttenlehm, die von oberirdischen Stockwerken stammen können, wurden in der Regel nicht ausgewertet. Ausgeprägtere Kollektionen wurden in Starý Hory entdeckt, massivere schwach gebrannte Schichten auf dem Kremsiger in Bau X (siehe unten). Ihre Herkunft kann jedoch auch mannigfaltig sein: von abgebrannten Fachwerkgiebeln über isolierte Decken bis hin zu Wänden von oberirdischen Häusern.

Neben den gängigen eingetieften Bauten wurden in Bergbausiedlungen in letzter Zeit auch außergewöhnliche Bauten gefunden. In Starý Hore - Mlékárny handelt es sich um einen zweiräumigen eingetieften Bau, der durch Brand zerstört wurde. Die Räume hatten eine unterschiedliche Fußbodenhöhe und waren durch eine Grundmauer aus Stein voneinander abgetrennt. Die Abmessungen des nicht vollständig erhaltenen Baus kann auf $5 \times 6 \mathrm{~m}$ geschätzt werden, die Tiefe von der ursprünglichen Oberfläche bewegte sich in einer Spanne von 1,2 bis 1,5 m. Auf dem Boden eines der Räume lag parallel gelagertes abgebranntes Holz, möglicherweise von einer Balkendecke.

Auf dem Kremsiger wurde außer zwei weiteren eingetieften Bauten ein großer zweiräumiger eingetiefter Bau X ausgehoben. Der westliche Teil war $10 \mathrm{~m}$ lang, der östliche 6,25 m. Die Breite des westlichen Teils beträgt 5,06 m, der östliche Teil hatte wohl eine ähnliche Breite. Die Grubentiefe des westlichen Teils reichte bis zu 2,66m unter das heutige Gelände, der östliche Teil 2,46m. Der Boden des östlichen Teils des Raumes lag $35 \mathrm{~cm}$ unterhalb des Bodenniveaus der westlichen Räume. Besonderheiten des niedriger gelegenen Teils waren quer verlaufende Rinnen mit Balken im Boden, offenbar Spuren eines Holzfußbodens mit tragenden Balken. Bei diesem Bau könnte es sich um ein großes Alkohollager gehandelt haben, die in schriftlichen Quellen für Bergbausiedlungen erwähnt werden (Tomaschek 1897, Nr. 93, 66).

Trotz dieser Funde bleiben im 13. und 14. Jahrhundert Häuser mit eingetieften Räumen kleinerer Abmessungen im Umfeld des Bergbaus der Standardbautyp. W. Schwabenickys Auffassung, dass die in einigen Fällen in und außerhalb von Bergbausiedlungen registrierte $\mathrm{Zu}-$ schüttung von Kellern und ihre Überbauung mit oberirdischen, nicht unterkellerten Häusern den Verlust von Lagerräumen bedeuten und demnach darauf hindeuten würde, dass diese Räume keine unentbehrlichen Bestandteile von Bergbauhäusern gewesen seien, sondern Wohnprovisorien, erlauben wir uns, zu widersprechen. Vor allem können die aufgeführten Beispiele nicht verallgemeinert werden, und auch in ihrem Fall kennen wir die Geschichte der einzelnen Parzellen oder die Eigentumsverhältnisse etc. nicht. Den Siedlungen mit erhaltenem Geländerelief nach zu urteilen, wären diese „Provisorien“ auch bei den nicht selten gerade kurzlebigen Standorten (in der Regel 50-100 Jahre) bis zum Lebensende nicht zugeschüttet worden. Ein Vergleich mit unterkellerten Häusern in Dörfern zeigt, dass auch dort große Keller nicht unentbehrlich waren, trotzdem aber nach und nach aus dem städtischen Umfeld übernommen wurden. Wir nehmen an, dass es sich auch in Bergbausiedlungen um verschieden große Keller gehandelt haben könnte, die nicht aus einer Notwendigkeit heraus geschaffen wurden, sondern als Bestandteil eines kleineren Stadthaustyps wie er im vorhergehenden Jahrhundert im Reichsgebiet errichtet wurde und in der ersten Phase von Neugründungen einschließlich Bergbausiedlungen quasi um auf Nummer sicher zu gehen gebaut wurde. Im weiteren Leben einer Siedlung veränderte sich das Aussehen der Häuser und passte sich den realen Bedürfnissen an.

Trotz gewisser Eigenheiten des montanen Umfelds, die besonders durch einen freizügigeren Städtebau und offenbar auch durch kleinere Abmessungen der Häuser zum Ausdruck 
kommt, unterscheidet sich das montane Bauen nicht grundlegend vom städtischen, sodass dieses Phänomen auch fernerhin in beiden Siedlungstypen gleichzeitig untersucht werden muss.

In einem Exkurs wird die Methodik und Interpretation der geophysikalischen Untersuchungen näher beschrieben, die bei der Untersuchung von Bergbausiedlungen auf der Böhmisch-Mährischen Höhe neue Erkenntnisse liefern. Verwendet wurde ein Fluxgate-Magnetometer Förster Ferex 4.032 DLG, das als Gradiometer mit vier Sonden konstruiert wurde. Die Dichte der gemessenen Punkte betrug $0,25 \times 0,5 \mathrm{~m}$. Die Vermessung führte zur Detektion von Erzen, die bei einer polymetallischen Vererzung immer auch Fe enthalten. Ferner von verbrannten Feuerstellensteinen, metallurgischem Abfall und auch organischen Materialien. Im Falle der zugeschütteten Bauten in Vyskytná und Buchberg erbrachte die Detektion auch solche Details wie den schlauchförmigen Eingang der Bauten. In Cvilínek waren die Vermessungsbedingungen schlechter.

Die vorliegende Studie entstand bei der Umsetzung des Projektes Nachhaltige Entwicklung der Kulturlandschaft und Schutz historischer Denkmäler in Waldgebieten, Projektcode: TL02000111.

Jiří Crkal, Ústav archeologické památkové péče severozápadních Čech, v. v. i., J. Žižky 835/9, 43401 Most, Česká republika,Jiri.Crkal@seznam.cz

MUDr. Mgr. Kryštof Derner, Ústav archeologické památkové péče severozápadních Čech, v. v. i., J. Žižky 835/9, 43401 Most, Česká republika, kderner@seznam.cz

doc. Mgr. Petr Hrubý, Ph.D., Ústav archeologie a muzeologie Filozofické fakulty Masarykovy univerzity, Arna Nováka 1,602 00 Brno, Česká republika, 203010@mail.muni.cz,PetrSilberbergbau@seznam.cz

Dr. phil. Peter Milo, Ústav archeologie a muzeologie Filozofické fakulty Masarykovy univerzity, Kounicova 67a, 60200 Brno, Česká republika,101090@mail.muni.cz 
